University of Nebraska - Lincoln

DigitalCommons@University of Nebraska - Lincoln

Faculty Publications in the Biological Sciences

Papers in the Biological Sciences

2006

\title{
Microorganisms pumping iron: Anaerobic microbial iron oxidation and reduction
}

Karrie A. Weber

University of Nebraska-Lincoln, kweber@unl.edu

Laurie A. Achenbach

Southern Illinois University Carbondale, laurie@micro.siu.edu

John D. Coates

University of California, Berkeley, jdcoates@berkeley.edu

Follow this and additional works at: https://digitalcommons.unl.edu/bioscifacpub

Part of the Life Sciences Commons

Weber, Karrie A.; Achenbach, Laurie A.; and Coates, John D., "Microorganisms pumping iron: Anaerobic microbial iron oxidation and reduction" (2006). Faculty Publications in the Biological Sciences. 204.

https://digitalcommons.unl.edu/bioscifacpub/204

This Article is brought to you for free and open access by the Papers in the Biological Sciences at DigitalCommons@University of Nebraska - Lincoln. It has been accepted for inclusion in Faculty Publications in the Biological Sciences by an authorized administrator of DigitalCommons@University of Nebraska - Lincoln. 


\title{
Microorganisms pumping iron: Anaerobic microbial iron oxidation and reduction
}

\author{
Karrie A. Weber, ${ }^{1}$ Laurie A. Achenbach, ${ }^{2} \&$ John D. Coates ${ }^{1}$
}

\author{
1. Department of Plant and Microbial Biology, 271 Koshland Hall, University of California, Berkeley, \\ Berkeley, California, 94720 USA. \\ 2. Department of Microbiology, Southern Illinois University, Carbondale, Illinois, 62901 USA. \\ Corresponding author — John D. Coates, email jcoates@nature.berkeley.edu
}

\begin{abstract}
Iron ( $\mathrm{Fe}$ ) has long been a recognized physiological requirement for life, yet for many microorganisms that persist in water, soils and sediments, its role extends well beyond that of a nutritional necessity. Fe(II) can function as an electron source for iron-oxidizing microorganisms under both oxic and anoxic conditions and Fe(III) can function as a terminal electron acceptor under anoxic conditions for iron-reducing microorganisms. Given that iron is the fourth most abundant element in the Earth's crust, iron redox reactions have the potential to support substantial microbial populations in soil and sedimentary environments. As such, biological iron apportionment has been described as one of the most ancient forms of microbial metabolism on Earth, and as a conceivable extraterrestrial metabolism on other iron-mineral-rich planets such as Mars. Furthermore, the metabolic versatility of the microorganisms involved in these reactions has resulted in the development of biotechnological applications to remediate contaminated environments and harvest energy.
\end{abstract}

\section{Lithotrophic A lithotrophic organism uses an inorganic substrate (usually of mineral origin) to obtain energy for growth.}

Heterotrophic A heterotrophic organism requires organic compounds as a carbon source.
At $\mathrm{pH}$ values at or above a circumneutral $\mathrm{pH}(\sim \mathrm{pH}$ $7)$, iron (Fe) exists primarily as insoluble, solidphase minerals in the divalent ferrous (Fe(II)) or trivalent ferric $(\mathrm{Fe}(\mathrm{III}))$ oxidation states ${ }^{1}$. The solubility of $\mathrm{Fe}(\mathrm{III})$ increases with decreasing $\mathrm{pH}$ values ${ }^{2}$. Decreasing $\mathrm{pH}$ values also enhance the stability of $\mathrm{Fe}(\mathrm{II})$, and below $\mathrm{pH} 4.0, \mathrm{Fe}(\mathrm{II})$ primarily exists as an aqueous species, even in the presence of oxygen. The biogeochemical role of Fe(II)-oxidizing microorganisms (FOM) in acidic environments has been well established (reviewed in Reference 3). At a circumneutral $\mathrm{pH}$, microbial iron redox cycling can significantly affect the geochemistry of hydromorphic soils (that is, soils showing poor drainage) and sediments, leading to the degradation of organic matter, mineral dissolution and weathering, the formation of geologically significant minerals, and the mobilization or immobilization of various anions and cations, including contaminants. ${ }^{1,4,5}$

The redox transition between the $\mathrm{Fe}(\mathrm{II})$ and $\mathrm{Fe}(\mathrm{III})$ valence states has a fundamental role in modern environmental biogeochemistry and was probably an important biogeochemical process on early Earth. Before microbially mediated iron redox reactions were discovered, abiotic mechanisms were thought to dominate environmental iron redox chemistry. However, it is now accepted that microbial metabolism primarily controls iron redox chemistry in most environments. Microorganisms from both the Archaea and Bacteria domains are capable of metabolically exploiting the favourable redox potential between the $\mathrm{Fe}(\mathrm{III}) / \mathrm{Fe}(\mathrm{II})$ couple and various electron donors or acceptors. In this way, $\mathrm{Fe}(\mathrm{II})$ is used as an electron donor to provide reducing equivalents for the assimilation of carbon into biomass by lithotrophic FOM under both oxic and anoxic conditions, and Fe(III) can be used as a terminal electron acceptor under anaerobic conditions for lithotrophic and heterotrophic Fe(III)-reducing microorganisms (FRM) (Figure 1). This Review discusses the intricate biogeochemical role of microbially mediated iron oxidation and reduction in suboxic environments, detailing the metabolisms, the microorganisms and the mechanisms described so far.

\section{Iron cycling: the microbial redox workout}

In the anoxic zone of neoteric environments at $\mathrm{pH}$ $>4.0, \mathrm{Fe}(\mathrm{III})$ oxides are readily reduced and provide an important electron sink for both chemical and biological processes. It is now established that microbial reduction of $\mathrm{Fe}(\mathrm{III})$ oxide minerals by FRM primarily controls the Fe(III)-reductive process in non-sulphidogenic sedimentary environments $^{6}$ (Figure 1). Even in some sulphidogenic environments (for example, some marine sediments) where $\mathrm{Fe}(\mathrm{III})$ reduction is traditionally thought to result from an abiotic reaction with biogenic hydrogen sulphide $\left(\mathrm{H}_{2} \mathrm{~S}\right)$, direct enzymatic Fe(III) reduc- 
tion by FRM has been shown to be substantial, and the activity of these organisms might account for as much as $90 \%$ of the oxidation of organic matter ${ }^{7}$. Organic carbon compounds are not the only electron donors that FRM are capable of utilizing. These microorganisms are also capable of utilizing inorganic electron donors such as hydrogen $\left(\mathrm{H}_{2}\right)$ (reviewed in Reference 6). Ammonium might have a role in $\mathrm{Fe}(\mathrm{III})$ reduction as an electron donor ${ }^{8}$, however, direct pure-culture evidence is still required to support this observation. The activity of FRM results in the generation of aqueous $\mathrm{Fe}(\mathrm{II})\left(\mathrm{Fe}(\mathrm{II})_{\mathrm{aq}}\right.$ ), and solid-phase $\mathrm{Fe}(\mathrm{II})$-bearing minerals (Fe(II) $)_{\mathrm{s}}$ ) including siderite, vivianite and geologically significant mixed-valence Fe(II)-Fe(III) minerals, such as magnetite and green rust. ${ }^{9}, 10$ The ubiquity and phylogenetic diversity of FRM, combined with the elemental abundance of iron in the earth's crust, establishes the global significance of this metabolic process. ${ }^{6}$

Similarly, microbially mediated Fe(II) oxidation is also known to contribute to the dynamic iron biogeochemical cycle at circumneutral $\mathrm{pH}$ in both oxic and anoxic environments (Figure 1). The recent identification of FOM in various aquatic and sedimentary systems - both freshwater and marine indicates that Fe(II) undergoes both biotic and abiotic oxidation in the environment. Abiotic oxidation of $\mathrm{Fe}(\mathrm{II})_{\mathrm{aq}}$ can be mediated by reaction with oxidized manganese $(\mathrm{Mn}(\mathrm{IV}))$ species or by the diffusion of $\mathrm{Fe}(\mathrm{II})_{\mathrm{aq}}$ into an oxic environment where it subsequently reacts with molecular oxygen $\left(\mathrm{O}_{2}\right)$. Disruption of sediments by macrophytes and macrofauna can induce particle mixing and aeration, resulting in the subsequent oxidation of both $\mathrm{Fe}(\mathrm{II})_{\mathrm{aq}}$ and $\mathrm{Fe}(\mathrm{II})_{\mathrm{s}}$ (References 11, 12). However, so far, microbially mediated oxidative processes in direct association with bioturbation have not been studied to any significant extent, with such studies being limited to the rhizosphere. ${ }^{13,14,15}$ Microaerophilic FOM capable of competing with the abiotic oxidation kinetics between oxygen and Fe(II) have been shown to contribute to iron cycling in oxic environments, coupling this metabolism to growth. ${ }^{16,17,18,19}$

Although the aerobic microbial oxidation of Fe(II) has been recognized for decades, the recent identification of anaerobic $\mathrm{Fe}(\mathrm{II})$ bio-oxidation closed a missing gap in the iron redox cycle. ${ }^{20}$, 21 Recent evidence indicates that anaerobic Fe(II) oxidation can contribute to a dynamic anaerobic iron redox cycle $22,23,24$, in addition to soil and sediment biogeochemistry, mineralogy, and heavymetal and radionuclide immobilization., 5, 24, 25 In anoxic environments, microbial Fe(II) oxidation has been demonstrated to be coupled to the reduction of nitrate, perchlorate and chlorate $21,24,26$ (Figure 1). These FOM can oxidize Fe(II) (References $4,25)$, and $\mathrm{Fe}(\mathrm{II})$ associated with structural iron in minerals, such as the iron aluminum silicate almandine $\left(\mathrm{Fe}_{3} \mathrm{Al}_{2}\left(\mathrm{SiO}_{4}\right)_{3}\right)$ or staurolite $\left((\mathrm{Fe}, \mathrm{Mg}, \mathrm{Zn})_{2}\right.$ $\mathrm{Al}_{9 y}(\mathrm{Si}, \mathrm{Al})_{4} \mathrm{O}_{22}(\mathrm{OH})_{2}$ ) (References 4, 27). In zones of sufficient light penetration, $\mathrm{Fe}(\mathrm{III})$ can also be produced through the activity of Fe(II)-oxidizing phototrophic bacteria that utilize $\mathrm{Fe}(\mathrm{II})$ as a source of electrons to produce reducing equivalents for the assimilation of inorganic caßrbon (Figure 1). FOM are ubiquitous and have been identified in numerous environments. Anaerobic, biogenically formed

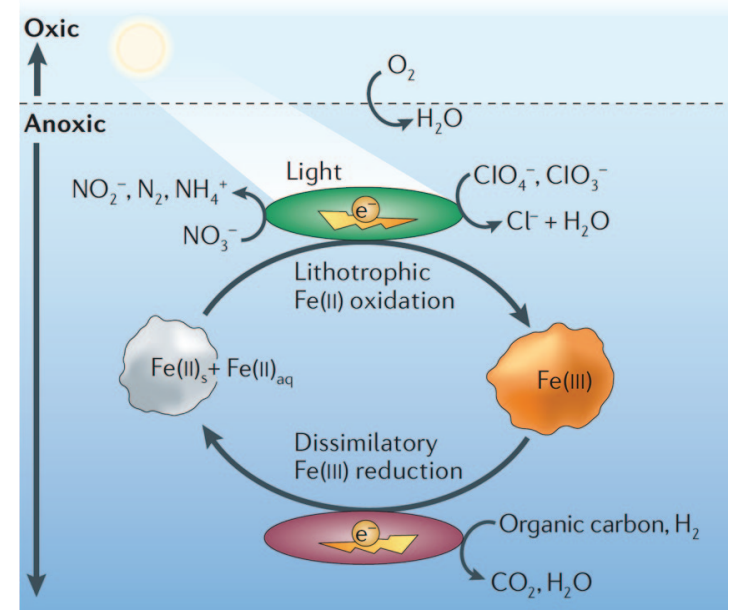

Figure 1. The microbially mediated iron redox cycle. Microorganisms have a significant role mediating iron oxidation and reduction reactions in soils and sedimentary environments. The reduction of Fe(III) oxides occurs in the absence of oxygen. The re-oxidation of the biogenic Fe(II) can occur through several biological mechanisms and is not simply limited to abiotic reactions with molecular oxygen. The regeneration of $\mathrm{Fe}$ (III) in the anoxic environment promotes a dynamic iron redox cycle.

Fe(III) oxides produced through the activity of these organisms potentially function as terminal electron acceptors for FRM, thereby perpetuating a dynamic microbially mediated iron redox cycle (Figure 1).

\section{Microbial Fe(II) oxidation}

The microbial oxidation of Fe(II) coupled to the reduction of oxygen in environments at acidic and circumneutral $\mathrm{pH}$ values has been recognized for more than a century (References 16, 28 and references therein). Yet, despite this historical knowledge, the geological significance of aerobic Fe(II) oxidation at circumneutral $\mathrm{pH}$ had been discounted based on the rapid rate of abiotic $\mathrm{Fe}(\mathrm{II})$ oxidation coupled to oxygenreduction ${ }^{29}$. It is now known that a broad diversity of microorganisms exist that are capable of aerobic, neutrophilic fe(II) oxidation and, although only three genera (Gallionella, Leptothrix and Marinobacter) have been described so far, several microaerophilic neutrophilic FOM were recently identified belonging to the $\alpha_{-}^{-}, \beta-$, and $\gamma$-proteobacteria ${ }^{19,30}$.

The environments that could potentially support aerobic, neutrophilic $\mathrm{Fe}(\mathrm{II})$ oxidation are stream sediments, groundwater iron seeps, wetland surface sediments, sediments associated with the rhizosphere, cave walls, irrigation ditches, subsurface bore holes, municipal and industrial water distribution systems, deep-ocean basalt and hydrothermal vents ${ }^{30}$. In these environments, microaerophilic FOM seem to successfully compete with the kinetics of abiotic Fe(II) oxidation. Although the quantitative significance of this microbial metabolic process in terms of accelerating Fe(II) oxidation rates is subject to interpretation, there is unequivocal evidence to demonstrate that FOM can conserve energy from this process and convert inorganic carbon, in the form of carbon dioxide $\left(\mathrm{CO}_{2}\right)$, into biomass ${ }^{17}$.

\section{Suboxic}

An environment with a partial pressure of oxygen that is substantially lower than the atmospheric oxygen content.

\section{Anoxic}

An environment lacking oxygen.

\section{Neoteric environments Modern environments. \\ Electron sink \\ A compound that receives electrons as an endpoint of an oxidative reaction.}

\section{Bioturbation}

The disturbance of sediment

layers by biological activity.

\section{Microaerophilic} An organism that is an obligate anaerobe but can survive in environments where the partial pressure of oxygen is substantially lower than in the atmosphere.

Phototrophic A phototrophic organism obtains energy for growth from sunlight; carbon is derived from inorganic carbon (carbon dioxide) or organic carbon.

\section{Neutrophilic} Fe(II) oxidation Microbial Fe(II) oxidation that occurs at circumneutral $\mathrm{pH}$ values $(\sim \mathrm{pH}$ 7). 


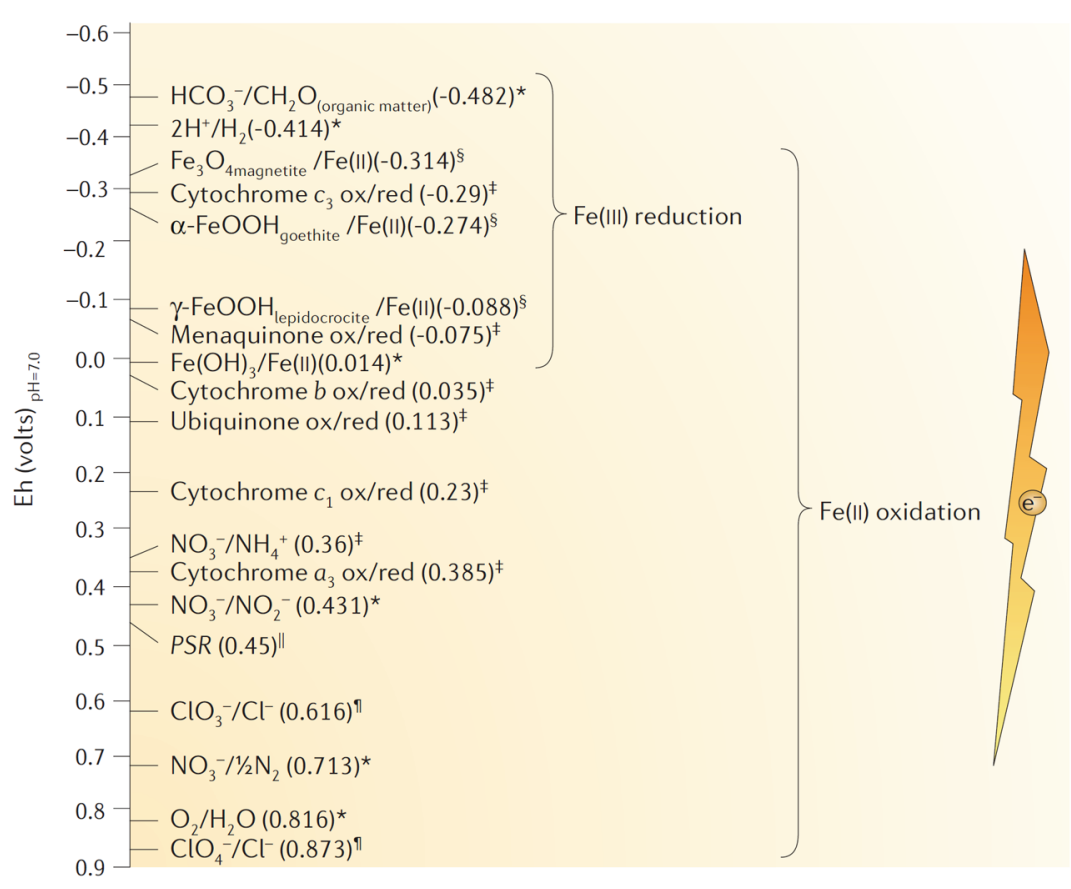

Figure 2. Potential electron donors and acceptors: a redox tower. Theoretical Eh (volts) values for reduction-oxidation couples that are significant to microbially mediated iron redox cycling, calculated at circumneutral $\mathrm{pH}$, are shown. The redox tower is an effective way to visualize the potential electron donors and acceptors utilizable by microorganisms measuring the tendency of a compound to interact as an electron donor or acceptor. An electron donor will have a greater negative potential than the electron acceptor will. The directional flow of electrons (e-) is denoted by the orange (negative) to yellow (positive) bolt. Reduction potentials were obtained from the following sources: "Reference $149,{ }^{\ddagger}$ Reference 101 , ${ }^{\S}$ Reference 150 and llReference 151. "Calculated based on data collected from References $2 \& 48$.

Aerobic Fe(II) oxidation not only has a role in iron redox reactions at the oxic-anoxic interface, it also influences mineral weathering in the environment ${ }^{19}$.

Before oxygen was available in the $\mathrm{Fe}(\mathrm{II})$-rich Precambrian environment, anaerobic microbial oxidation of $\mathrm{Fe}(\mathrm{II})$ potentially provided an early respiratory metabolism, contributing to the precipitation of iron oxide minerals, including magnetite ${ }^{4,20,31}$ 32. The reduction potential of the Fe(III)/Fe(II) couple is sufficient to provide reducing power between bacterial photosystems or alternative terminal electron acceptors involved in respiratory processes (Figure 2) to sustain microbial growth. In the past decade the true extent of this metabolism has been realized and anaerobic $\mathrm{Fe}(\mathrm{II})$ oxidation mediated by members of both the Archaea and Bacteria domains has been described in anoxic environments at circumneutral $\mathrm{pH}^{20,21,31}$.

Seeing the light - anaerobic, photoautotrophic oxidation of $\mathrm{Fe}(\mathrm{II})$. The discovery of photoautotrophic, anaerobic Fe(II) oxidation was the first demonstration of microbially mediated oxidation of $\mathrm{Fe}(\mathrm{II})$ in anoxic environments ${ }^{20}$. The FOM involved in this process oxidize $\mathrm{Fe}(\mathrm{II})$, utilizing light energy to fix $\mathrm{CO}_{2}$ into biomass as shown below.

$\mathrm{HCO}_{3}{ }^{-}+4 \mathrm{Fe}(\mathrm{II})+10 \mathrm{H}_{2} \mathrm{O} \rightarrow \mathrm{CH}_{2} \mathrm{O}+4 \mathrm{Fe}(\mathrm{OH})_{3}+7 \mathrm{H}^{+}$

Although the phototrophic FOM in the Bacteria domain are phylogenetically diverse, including
Chlorobium ferrooxidans, Rhodovulum robiginosum, Rhodomicrobium vannielii, Thiodictyon sp., Rhodopseudomonas palustris and Rhodovulum spp. (Figure 3), so far, an archaeon capable of this metabolism has not been identified.

Several purple and green anaerobic, anoxygenic, photosynthetic FOM have been isolated from freshwater and marine environments and described in pure culture $20,32,33,34,35,36$. With the exception of $R$. vannielii, these phototrophic FOM can completely oxidize $\mathrm{Fe}(\mathrm{II})_{\mathrm{aq}}$ to $\mathrm{Fe}(\mathrm{III})$. Incomplete Fe(II) oxidation by $R$. vannielii has been attributed to encrustation of the bacterial cell with biogenic $\mathrm{Fe}(\mathrm{III})$ oxides, inhibiting further metabolic activity ${ }^{20}, 34$. The production of low-molecular-weight compounds that can solubilize biogenic Fe(III) has been suggested as a mechanism for preventing cell encrustation in cultures of other phototrophic FOM, including $R$. robiginosum and C. ferrooxidans ${ }^{33,}$ 37. In contrast to $R$. vannielii ${ }^{37}$, the concentrations of soluble $\mathrm{Fe}(\mathrm{II})$ and $\mathrm{Fe}(\mathrm{III})$ in spent culture media of $R$. robiginosum and C. ferrooxidans far exceeded the amount predicted by solubility constants and an uninoculated control ${ }^{37}$. However, a subsequent study failed to find significant evidence to support a direct role for organic compounds or chelators complexing iron when $R$. robiginosum, C. ferrooxidans and Thiodictyon sp. strain F4 were grown on $\mathrm{Fe}(\mathrm{II})_{\mathrm{aq}}$ or solid-phase ferrous sulphide $(\mathrm{FeS})^{38}$. As such, it was proposed that Fe(III) was released from the active cell as an inorganic aqueous complex or colloidal aggregate ${ }^{38}$. Nonetheless, it remains to be explained why $R$. vannielii is subject to cell encrustation whereas the other phototrophic FOM are not affected. The production of compounds capable of solubilizing $\mathrm{Fe}(\mathrm{III})$ has profound implications not only for FOM cellular metabolism but also for the dissolution of solid-phase minerals and the release of soluble iron as a terminal electron acceptor or a micronutrient for other aquatic and terrestrial living organisms.

Phototrophic Fe(II) oxidation results in the formation of poorly crystalline Fe(III) oxides, which subsequently transform into the more crystalline $\mathrm{Fe}(\mathrm{III})$ oxide minerals goethite and lepidocrocite in the presence of metabolically active $\mathrm{FOM}^{38}$. However, the significance of phototrophic Fe(II) oxidation processes in natural terrestrial environments is limited by the maximum penetration of light to a depth of $200 \mu \mathrm{m}$ in soil and sediments ${ }^{39}$. Furthermore, recent studies indicate that phototrophic FOM are unable to promote Fe(II) mineral dissolution and are limited by the mineral solubility ${ }^{38}$. Therefore, the impact of this microbial process on iron redox cycling and mineral weathering might be significant locally but of only minor importance in global iron biogeochemical cycling in terrestrial environments.

Working in the dark - anaerobic, nitrate-dependent Fe(II) oxidation. Anaerobic Fe(II) oxidation is not limited to environments exposed to light. At circumneutral $\mathrm{pH}$, light-independent microbially mediated oxidation of both soluble and insoluble Fe(II) coupled to nitrate reduction has been demonstrated in various freshwater and saline environmental systems, including paddy soil, pond, stream, ditch, brackish lagoon, lake, wetland, aquifer, hydrother- 


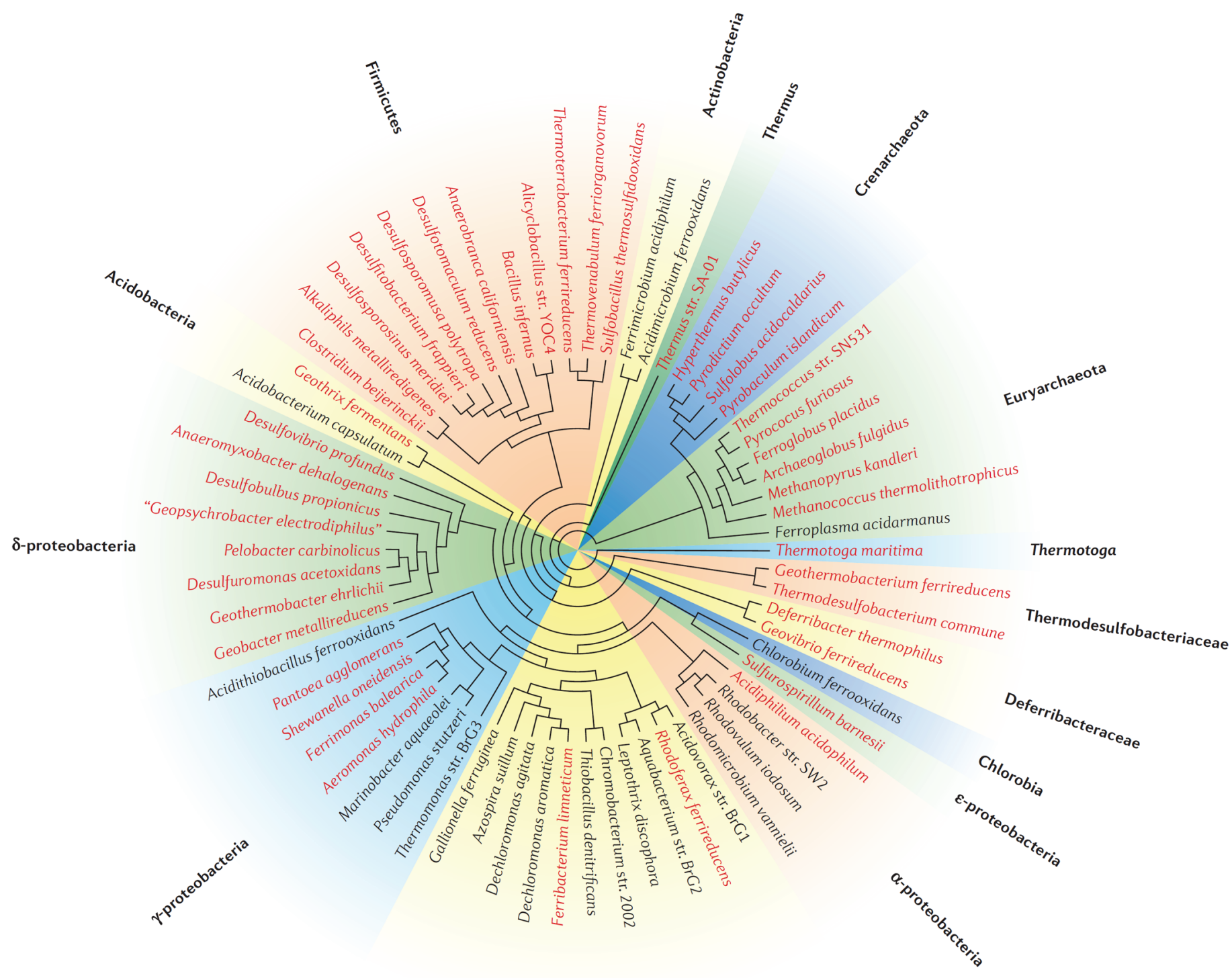

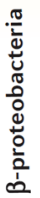

Figure 3. Phylogenetic affiliation of microorganisms contributing to iron redox cycling. Unrooted phylogenetic tree based on nearly complete $16 \mathrm{~S}$ ribosomal DNA sequences from representative iron cycling prokaryotes. The names of iron reducers are given in red text, iron oxidizers are given in black text.

mal, and deep-sea sediments ${ }^{4}, 19,21,25,27,31,40,41,42$, 43. These environmental systems support abundant nitrate-dependent $\mathrm{Fe}(\mathrm{II})$-oxidizing microbial communities in the order of $1 \times 10^{3}$ to $5 \times 10^{8}$ cells $\mathrm{g}^{-1}$ sediment (Reference 44 and references therein), potentially contributing to iron redox cycling.

Various archaeal and bacterial genera (Figure 3), representing a range of optimal thermal growth conditions (from psychrophilic through mesophilic to hyperthermophilic), have been identified. The ubiquity and diversity of these anaerobic FOM suggests that metabolic, light-independent reactions such as nitrate-dependent Fe(II) oxidation have the potential to contribute to anoxic $\mathrm{Fe}(\mathrm{II})$ oxidation on a global scale, provided that adequate concentrations of a suitable electron acceptor are readily available. In environments where zones of nitrate reduction and $\mathrm{Fe}(\mathrm{III})$ reduction merge, this metabolism not only influences the iron cycle but can also influence the nitrogen cycle. However, the quantitative significance of this metabolism to global nitrogen cycling is currently unknown.

So far, FOM have been demonstrated to exploit the favourable thermodynamics between $\mathrm{Fe}\left(\mathrm{OH}_{3}\right)$ / $\mathrm{Fe}(\mathrm{II})$ and nitrate reduction redox pairs $\left(\mathrm{NO}_{3}^{-} / 1 / 2 \mathrm{~N}_{2}\right.$, $\mathrm{NO}_{3}^{-} / \mathrm{NO}_{2}^{-}$and $\left.\mathrm{NO}_{3}^{-} / \mathrm{NH}_{4}^{+}\right)^{21,} 24,26,31$, and between $\mathrm{Fe}\left(\mathrm{OH}_{3}\right) / \mathrm{Fe}(\mathrm{II})$ and perchlorate $\left(\mathrm{ClO}_{4}^{-} / \mathrm{Cl}^{-}\right)$ and chlorate $\left(\mathrm{ClO}_{3}^{-} / \mathrm{Cl}^{-}\right)^{26}$ (Figure 2$)$. Several phylo-
Psychrophilic An organism that grows optimally in a cold environment $\left(<15^{\circ} \mathrm{C}\right)$.

\section{Mesophilic}

An organism that grows optimally in a moderate environment $\left(\sim 25-45^{\circ} \mathrm{C}\right)$.

Hyperthermophilic An organism that grows optimally in hot environments $\left(>80^{\circ} \mathrm{C}\right)$. 


\section{Autotrophic}

An autotrophic organism uses inorganic carbon (carbon dioxide) as a carbon source.

\section{Chemolithoau-} totrophic An organism that obtains energy from inorganic compounds and carbon from carbon dioxide. gentically diverse mesophiles have been described as being capable of nitrate-dependent Fe(II) oxidation (Figure 3). However, in most cases growth was either not associated with this metabolism or was not demonstrated in the absence of an additional electron donor or organic carbon as an energy source at circumneutral $\mathrm{pH}^{4,21,26,27}$. The oxidation of $\mathrm{Fe}(\mathrm{II})$, including $\mathrm{Fe}(\mathrm{II})_{\mathrm{s}^{\prime}}$ coupled to nitrate reduction is energetically favourable at neutral $\mathrm{pH}$ and should yield enough energy to support carbon fixation and microbial growth. However, so far autotrophic growth under nitrate-dependent $\mathrm{Fe}(\mathrm{II})$-oxidizing conditions has only been demon- strated in two pure-culture isolates; a hyperthermophilic archaeon, Ferroglobus placidus ${ }^{31}$, and a mesophilic $\beta$-proteobacterium, strain 2002 (Reference 45). Even in the case of a known Fe(II)-oxidizing chemolithoautotrophic bacterium, Thiobacillus denitrificans, energy conservation directly coupled to the nitrate-dependent oxidation of Fe(II) could not be demonstrated without an additional electron donor ${ }^{46}$. Nitrite $\left(\mathrm{NO}_{2}{ }^{-}\right)$and nitrogen gas $\left(\mathrm{N}_{2}\right)$ were thought to be the sole end products of nitrate reduction $^{4,21,31}$ until the recent demonstration of nitratedependent Fe(II) oxidation by Geobacter metallireducens resulting in the production of ammonium ${ }^{24}$.

\section{Box 1. Banded iron formations}

The deposition of alternating iron-rich and silica-rich mineral layers in the late Fe(II)-rich Archean to early Proterozoic periods of the Earth's history resulted in the genesis of the Precambrian banded iron formations (BIFs) ${ }^{125}$ (see figure). Early models suggested that BIFs were a consequence of abiotic reactions involving Fe(II) photo-oxidation ${ }^{51}$ 126 and/or Fe(II) oxidation by the metabolic end product of oxygenic photosynthesis - oxygen (Reference 127). This led to the formation of the iron-rich laminae, containing hematite $\left(\mathrm{Fe}_{2} \mathrm{O}_{3}\right)$ and the mixed-valence phase $\mathrm{Fe}(\mathrm{II})-$ $\mathrm{Fe}$ (III)-bearing mineral magnetite $\left(\mathrm{Fe}_{3} \mathrm{O}_{4}\right)$.

In recent years, microbial reductive and oxidative respiratory metabolisms have been implicated in the deposition of iron-bearing minerals in the iron-rich laminae of $\mathrm{BIFs}^{4,20,128,129,130}$. Microaerophilic Fe(II) oxidizers, such as Gallionella ferruginea, might have metabolically oxidized Fe(II) coupled to the oxygen generated by oxygenic photosynthesis ${ }^{129,131}$. However, this model assumes that oxygenic photosynthesis evolved enough oxygen to account for the precipitation of Fe(III)-rich minerals. There has been much debate concerning the evolution of oxygen in the early Proterozoic and therefore the role of oxygen in the deposition of BIFs ${ }^{132,133}$. Other microbially mediated mechanisms influencing the precipitation of Fe(II)- and Fe(III)-rich minerals in anoxic environments have been proposed as plausible alternatives, including Fe(III) reduction, phototrophic Fe(II) oxidation, and nitrate-dependent Fe(II) oxidation (see figure).

The precipitation of magnetite associated with microbial Fe(III) reduction linked the deposition of BIFs to FRM ${ }^{9}$ 53. Yet the generation of $\mathrm{Fe}(\mathrm{III})$ as a terminal electron acceptor from available $\mathrm{Fe}$ (II) would have to precede metabolic Fe(III) reduction. In addition to photo-oxidation, the anoxic deposition of Fe(III) oxides by photoautotrophic ${ }^{20,130}$ and nitrate-dependent Fe(II)-oxidizing microorganisms ${ }^{4}$ (FOM) during the late Archean to the early Proterozoic has been proposed (see figure). However, the bio-oxidation of Fe(II) not only results in the precipitation of Fe(III) oxides but also results in the direct precipitation of magnetite ${ }^{4,32,36}$ and hematite ${ }^{4}$, potentially linking FOM directly to the formation of BIFs. The availability of light in the Precambrian is inarguable, as such phototrophic Fe(II) oxidation has received much attention as a model for BIF deposition ${ }^{130}$. By contrast, light-independent Fe(II) oxidation coupled to nitrate reduction has received much less attention as a model; however, it does provide an additional mechanism leading to BIF formation in the Precambrian and, in contrast to known phototrophic FOM, extant nitrate-dependent FOM have been shown to produce significant quantities of extracellular magnetite and hematite ${ }^{4,32,36}$. Lightning discharge contributed to the fixation of nitrogen $\left(\mathrm{N}_{2}\right)$ into nitric oxide ( $\mathrm{NO}\left(\sim 10^{12} \mathrm{~g}\right.$ per $\left.\mathrm{yr}\right)$ further forming nitrous oxide $\left(\mathrm{N}_{2} \mathrm{O}\right)$, the nitrite ion $\left(\mathrm{NO}_{2}^{-}\right)$and the nitrate ion $\left(\mathrm{NO}_{3}^{-}\right)$through abiotic disproportion reactions ${ }^{134,}{ }^{135}$. Such oxidized nitrogen species could have functioned as an electron acceptor for early FOM, leading to BIFs in anoxic environments.

In modern environmental systems, complex microbial communities contribute to a dynamic anoxic iron redox cycle. Similarly complex communities consisting of phototrophic FOM, nitrate-dependent FOM and Fe(II)-reducing microorganisms (FRM) might have existed in the Precambrian era, each of which contributed to the formation of the BIFs rather these being the result of one individual metabolism. The precipitation of biomass with biogenic Fe(III) oxides would contribute to diagensis and mineralization of organic matter, resulting in heterotrophic reduction of Fe(III) by FRM and the formation of additional magnetite in BIFs ${ }^{53,130}$, which is further supported by the isotopically light carbon associated with BIFs ${ }^{136}$.

The figure shows the models proposed for the microbial mediation of anoxic deposition of BIF. The deposition of Fe-rich laminae, hematite and magnetite, could be a result of anoxic microbial metabolisms. The direct oxidation of $\mathrm{Fe}(\mathrm{II})$ by photoautotrophic bacteria (a) and nitrate-dependent Fe(II) oxidizing bacteria (b) results in the formation of magnetite and hematite, and solid-phase Fe(III) oxides. The biogenic Fe(III) oxides are subsequently reduced by FRM (c) forming magnetite.

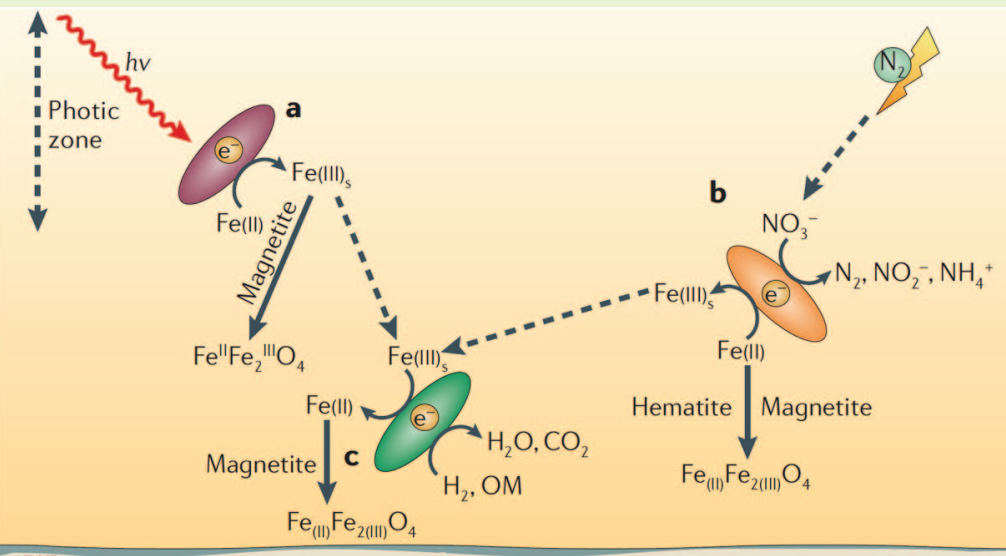


Growth of FOM that are capable of autotrophy or mixotrophy associated with perchlorate/chlorate-dependent $\mathrm{Fe}(\mathrm{II})$ oxidation has not yet been identified. However, perchlorate/chlorate-dependent Fe(II)-oxidizing metabolic activity is observed in stationary-phase cultures of Dechloromonas agitata and Azospira suillum strain PS (previously called Dechlorosoma suillum) containing acetate, perchlorate and $\mathrm{Fe}(\mathrm{II})$ (References 4, 47). Although perchlorate and chlorate are not naturally abundant compounds, their potential to serve as electron acceptors in environmental systems cannot be discounted $^{48}$. The legal discharge of perchlorate into natural waters has led to widespread anthropogenic contamination throughout the United States. Given the ubiquity of perchlorate-reducing bacteria ${ }^{48}$ and the ability of some of these microorganisms, specifically A. suillum and D. agitata, to oxidize Fe(II), anaerobic perchlorate/chlorate-dependent Fe(II) oxidation could affect iron biogeochemical cycling in environments exposed to contaminated waters. Further studies are needed to quantify the potential influence of perchlorate/chlorate-dependent Fe(II) oxidation.

Doing hard time: solid-phase microbial Fe(II) oxidation. In contrast to the reaction carried out by phototrophic FOM, Fe(II) including surfacebound Fe(II) (References 24, 25), crystalline Fe(II) minerals (siderite, magnetite, pyrite, arsenopyrite and chromite $)^{4,25}$, and structural Fe(II) in neosilicate (almandine and staurolite) ${ }^{4}$ and phyllosilicate (nontronite) ${ }^{27}$ are known to be subject to direct nitrate-dependent microbial oxidation. Although we know that nitrate-dependent FOM have a role in the oxidation of $\mathrm{Fe}(\mathrm{II})$ that is structurally incorporated into silicate minerals, and contribute to Fe(II) mineral dissolution, little is known about the mineral structure and stability of the residual material. The oxidative dissolution of $\mathrm{Fe}(\mathrm{II})$ ${ }_{s}$ in anoxic environments presents an additional mechanism for rock weathering and the precipitation of Fe(III) oxide minerals in anoxic soils and sediments. So far, bio-oxidation products of Fe(II) aq and amorphous $\mathrm{Fe}(\mathrm{II})_{\mathrm{s}}$ have been characterized. Various biogenic Fe(III) oxide minerals, including 2-line ferrihydrite ${ }^{40,47}$, goethite ${ }^{24}$, lepidocrocite (J. D.C. and K.W., unpublished data) and hematite ${ }^{4}$, and mixed-phase Fe(II)-Fe(III) minerals, magnetite, maghemite and green rust ${ }^{4}$ (J.D.C. and K.W., unpublished data), were identified as oxidation products. As a result of this biogenic formation of magnetite and hematite, nitrate-dependent $\mathrm{Fe}(\mathrm{II})$ oxidation has been implicated as having a direct role in the genesis of banded iron formations in Precambrian Earth ${ }^{4}, 31$ (Box 1).

Function over form: physiology of anaerobic $\mathrm{Fe}(\mathrm{II})$ oxidation at circumneutral pH. Little is known about the biochemistry or genetic regulation of anaerobic Fe(II) oxidation at circumneutral $\mathrm{pH}$ and as such this can only be discussed in a general sense. The reduction potential of the possible Fe(III)/ Fe(II) redox pairs ranges from $-0.314 \mathrm{~V}$ to $+0.014 \mathrm{~V}$, indicating that electrons can readily be donated to the more electropositive type $b, c$, or $a$ cytochrome components of an electron transport chain (Figure 2). In support of this, previous studies using the known
FOM D. agitata and A. suillum demonstrated the involvement of $c$-type cytochrome(s) when grown under Fe(II)-oxidizing conditions with nitrate or chlorate, respectively ${ }^{4}, 26$.

The demonstrated capability of some FOM to use $\mathrm{CO}_{2}$ as the sole carbon source requires a $\mathrm{CO}_{2}-$ fixation pathway. In the case of the archaeon Ferroglobus placidus grown on $\mathrm{CO}_{2}$, the reductive acetyl coenzyme A pathway is expressed, implicating its involvement in carbon assimilation ${ }^{49}$. Interestingly, genes associated with the reductive pentose phosphate cycle, RuBisCo, were identified in the finished genome sequence of Dechloromonas aromatica, an Fe(II)-oxidizing bacterium capable of utilizing nitrate, chlorate or perchlorate as alternative electron acceptors ${ }^{45}$; however, autotrophic growth associated with Fe(II) oxidation could not be demonstrated and the conditions under which these genes are expressed remain unidentified (J.D.C., unpublished data). By contrast, PCR amplification using degenerative RuBisCo primers of the genomic DNA from strain 2002, the mesophilic autotrophic nitrate-dependent FOM, did not yield a PCR product ${ }^{45}$. The $\mathrm{CO}_{2}$-fixation pathway expressed in strain 2002 during growth under nitrate-dependent $\mathrm{Fe}(\mathrm{II})$-oxidizing conditions is currently unknown. Nonetheless, the availability of genomic sequence information for the FOM D. aromatica, Marinobacter aquaeolei, G. metallireducens, $R$. palustris, and T. denitrificans provides the first opportunity to comprehensively investigate the functional genes and regulatory pathways associated with this metabolism. However, the genomes of other phylogenetically and physiologically distinct microorganisms such as F. placidus, strain 2002 and A. suillum, which also potentially have a key role in anaerobic nitrate-dependent Fe(II) oxidation, have yet to be sequenced.

\section{The other half - microbial iron reduction}

Antiquity of iron reduction. It has been proposed that life emerged on a hot (possibly as high as 140$\left.150^{\circ} \mathrm{C}\right), \mathrm{Fe}(\mathrm{II})$-rich early Earth 3.8 billion years ago ${ }^{50}$. The abiotic photochemical generation of $\mathrm{Fe}(\mathrm{III})$ and $\mathrm{H}_{2}$ would have provided an electron acceptor and energy source, respectively, for ancient life, as shown below (References 6, 51 and references therein).

$$
2 \mathrm{Fe}(\mathrm{II})+2 \mathrm{H}^{+} \stackrel{h v}{\rightarrow} 2 \mathrm{Fe}(\mathrm{III})+\mathrm{H}_{2}
$$

As such, iron respiration has been proposed as one of the first forms of microbial metabolism to have evolved, preceding the development of oxygen, nitrate and sulphate respiration ${ }^{52,53}$. In support of this, $\mathrm{Fe}(\mathrm{III})$ respiration has been identified in a diversity of extant microorganisms including those most closely related to the last common ancestor ${ }^{52,54}$. Extracellular electron transfer to insoluble Fe(III) oxide minerals has been conserved in the hyperthermophilic Archaea ${ }^{52,54,55,56}$ and is widely distributed among the Bacteria ${ }^{6,53}$ (Figure $3)$, further suggesting that this is an early metabolism that has spread through the microbial domains throughout evolution.

\author{
Mixotrophy \\ A mixotrophic \\ organism uses \\ an inorganic \\ chemical \\ energy source \\ and organic \\ compounds as a \\ carbon source.
}



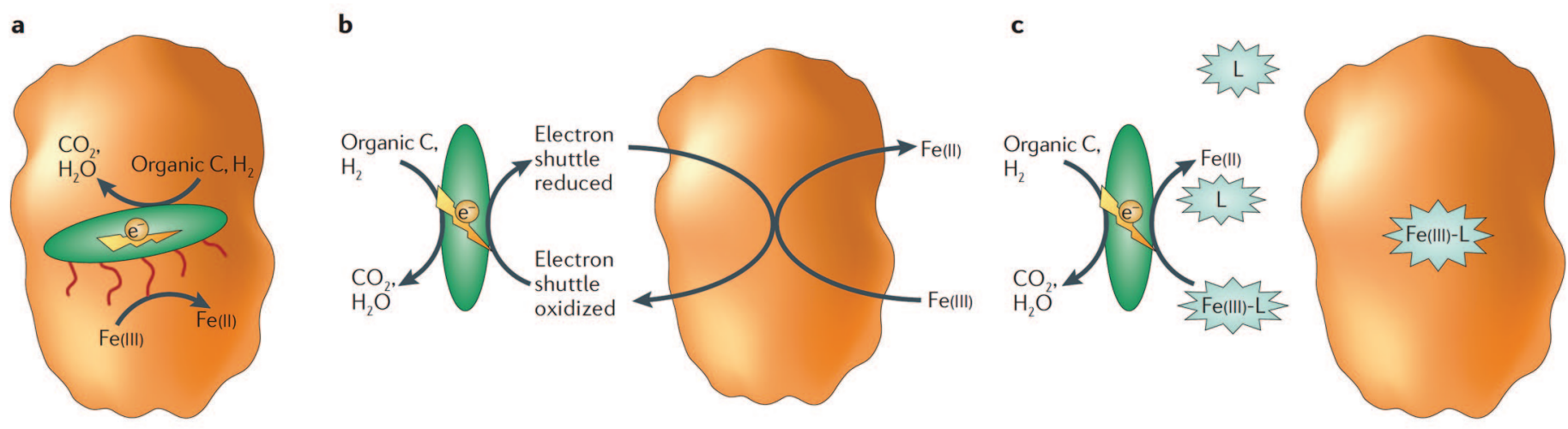

Figure 4. Microbial strategies mediating electron transfer to insoluble Fe(III) oxides. Three primary strategies have been proposed to facilitate the electron transfer between microorganisms and solid Fe(III) oxide surfaces. a) In Geobacter spp. direct contact with the oxide surface is required. The production of 'nanowires', conductive extracellular appendages, facilitates electron transfer by functioning as an electrical conduit to the Fe(III) oxide surface. b) An endogenously or exogenously produced electron shuttle mediates electron transfer to solid-phase Fe(III) oxides. c) The production of complexing ligands as in the case of Geothrix sp. aids in the dissolution of the solid-phase Fe(III) oxide providing a soluble Fe(III) form more readily available to the microorganism. Although these strategies have only been demonstrated for Fe(III)-reducing microorganisms, similar strategies might be used by Fe(II)-oxidizing microorganisms that are utilizing solid-phase Fe(II) electron donors. $\mathrm{e}^{-}=$electrons; $\mathrm{L}=$ ligand

A hard rock chord: crystalline Fe(III) oxide reduction. Poorly crystalline Fe(III) oxide minerals, such as ferrihydrite, readily function as electron acceptors for $\mathrm{FRM}^{6}$. This is not surprising, given the relative energetic favourability of the reduction of amorphous ferric iron oxides (Figure 2). However, iron oxides predominantly exist in a crystalline phase or as a structural component of clays in modern soils and sediments. Although the thermodynamic favourability of crystalline Fe(III) oxide mineral reduction (goethite, hematite and magnetite) is decreased compared with amorphous $\mathrm{Fe}(\mathrm{III})$ oxides (Figure 2), previous studies have suggested that FRM are capable of living 'on the energetic edge,' utilizing structural ${ }^{57}$ or crystalline solid-phase $\mathrm{Fe}(\mathrm{III})$ as an electron acceptor ${ }^{58,59}$. There has been considerable debate regarding the direct environmental relevance of the laboratory studies that have examined the reduction of crystalline iron minerals under artificial organic and nutrient-rich conditions to optimize FRM growth ${ }^{6}$, 60 . Glasauer and colleagues did not observe reduction of goethite and hematite in defined minimal media by Shewanella putrefaciens strain CN32, in direct contrast to previous reduction studies conducted with this organism in nutrient-rich media ${ }^{10}$, 59 . However the inability of FRM to reduce crystalline Fe(III) oxide minerals under nutrient-limited conditions is not a universal observation. Under oligotrophic culture conditions, both a culture of G. metallireducens and a freshwater enrichment culture (1\% vol:vol inoculum) reduced goethite beyond the amorphous Fe(III) oxide content (determined by $0.5 \mathrm{~N} \mathrm{HCl}$ extraction ${ }^{24}$, indicating the possibility for microbial reduction of crystalline $\mathrm{Fe}(\mathrm{III})$ oxides in the environment.

Between a rock and a hard place: microbial strategies for reduction of an insoluble electron acceptor. The insoluble nature of Fe(III) oxide minerals at values $>\mathrm{pH} 4$ creates a metabolic dilemma for microor- ganisms utilizing Fe(III) oxides as a respiratory terminal electron acceptor. Various mechanisms have been proposed as possible strategies that microorganisms might use to transfer electrons to extracellular Fe(III) oxide minerals. Direct contact between the microorganism and the solid-phase Fe(III) oxide mineral was shown to be a requirement for the reduction of insoluble Fe(III) oxides in Geobacter spp. ${ }^{61}$ (Figure 4A). The molecular scale interaction(s) occurring between the cell surface and Fe(III) oxide is currently unknown.

The formation of flagella and pili had been proposed as the mechanism by which Geobacter spp. directly attached to the Fe(III) oxide surface ${ }^{62}$. Recent evidence, however, indicates that pili are not required for attachment of Geobacter spp. to the solidphase Fe(III) oxide surface. Instead, the pili function as an electrical conduit for the transfer of electrons to insoluble Fe(III) oxides and, potentially, other solid-phase terminal electron acceptors ${ }^{63}$. The formation of these conductive cellular 'nanowires' expands the accessible spatial area available beyond the cell membrane, allowing the penetration of nanometer pore spaces in soils and sediments previously thought to be physically unavailable to the cell. The potential for these 'nanowires' to create a bridge between individual cells introduces the possibility of cell-to-cell communication ${ }^{63}$, and for the cell attached to the Fe(III) oxide or other electron acceptor to function as an electron shuttle.

Conductive 'nanowires' were thought to be exclusive to Geobacter spp. as pili produced by other metal-reducing organisms tested, including Shewanella oneidensis, were not conductive ${ }^{63}$. However, recent evidence indicates that $S$. oneidensis, among other microorganisms, also produce conductive appendages under conditions in which the electron acceptor is limited ${ }^{64}$. The direct involvement of these appendages in electron transport or reduction of $\mathrm{Fe}(\mathrm{III})$ remains unproven and their functional role is currently unknown. 
FRM might not necessarily need to establish direct contact with the solid-phase surface to reduce $\mathrm{Fe}(\mathrm{III})$ oxides, as other alternative active mechanisms could be used. Exogenous ${ }^{65}$ and endogenously produced $66,67,68$ soluble external electron shuttles can be exploited as mediators to complete the transfer of electrons to the solid-phase terminal electron acceptor (Figure 4B). The electron shuttle alleviates the need for the FRM to directly contact the Fe(III) oxide and functions in a combination of a microbially catalysed and abiotic process; the FRM oxidizes an electron donor coupled to the reduction of the soluble electron shuttle and the reduced electron shuttle diffuses and subsequently donates electrons to the solid-phase Fe(III) oxide abiotically $^{65}$ (Figure 4B). The abiotic regeneration of the oxidized electron acceptor restarts the cycle (Figure 4B).

Redox-reactive organic compounds common in soils and sediments, such as humic acids ${ }^{65}$, plant exudates $^{69}$ and antibiotics ${ }^{70}$, have been identified as electron shuttles. Although the significance of these compounds as electron shuttles for microbially mediated $\mathrm{Fe}(\mathrm{III})$ reduction in eutrophic environments is still unknown, their utility in oligotrophic environments might be limited owing to the low availability of suitable redox-reactive refractory organic substances. However, the endogenous production of an electron shuttle in two FRM genera, Shewanella ${ }^{66,68,71,72}$ and Geothrix 67 , and the production of a chelating ligand by Geothrix sp. (Fig 4c), could further mitigate the reliance of these FRM on exogenous electron shuttles.

Although the energetic expense of producing and excreting redox-reactive compounds into the environment would not yield a competitive advantage in situations of low cell mass, it has been speculated that the release of electron shuttles in a biofilm community would facilitate electron transfer by cells distant from the substrate surface. ${ }^{72}$ In addition, the recently identified ubiquitous biological re-oxidation of these diffusing electron shuttles, coupled to carbon assimilation in the presence of a suitable electron acceptor such as nitrate, offers the potential for a previously unidentified symbiotic relationship at the microbial level. ${ }^{73,74}$

The iron maidens: diversity of FRM. A wide phylogenetic diversity of microorganisms capable of conserving energy coupled to growth by the dissimilatory reduction of $\mathrm{Fe}(\mathrm{III})$ have been identified throughout the Archaea and Bacteria (Figure 3) and across a range of chemical and physical conditions, demonstrating the ubiquity of this type of microbial metabolism. Among the isolated microorganisms, $\mathrm{Fe}(\mathrm{III})$-reducing extremophiles including hyperthermophilic, thermophilic, psychrophilic, acidophilic and alkaliphilic Archaea and Bacteria have been described in pure culture ${ }^{54}, 75,76,77,78,79$ (see Lovley et al. $^{6}$ for a review). One such isolate surviving in hydrothermal vents has pushed the upper temperature limit for life above $121^{\circ} \mathrm{C}$ (Reference 54).

In modern terrestrial and subsurface environments at circumneutral $\mathrm{pH}$, microorganisms in the family Geobacteraceae are among the most common and most comprehensively studied FRM (Reference 6 and references therein). The Geobacteraceae are thought to have a significant role in dissimilatory $\mathrm{Fe}(\mathrm{III})$ reduction and the oxidation of organic matter in soils and sediments. Outside the $\delta$-proteobacteria, the genus Shewanella in the $\gamma$-proteobacteria is another well-characterized group of FRM. Although Shewanella spp. have been isolated from diverse metal-reducing sediments $^{80,81,82}$, several studies focused on recovering $16 \mathrm{~S}$ ribosomal DNA (rDNA) gene sequences representing these FRM from natural Fe(III)-reducing environments have not yielded a positive result ${ }^{83,84,85}$. As a result, these data indicated that these microorganisms might only have a minor role in the reduction of Fe(III) oxides in situ. However, this result might not be universal; the recent identification of $16 \mathrm{~S}$ rDNA gene sequences closely related to Shewanella spp. in a minerotrophic wetland indicates the potential for this group of FRM to contribute to iron cycling in situ ${ }^{86}$.

Recent evidence indicates that other organisms belonging to the $\beta$-proteobacteria might also have a role in the reduction of Fe(III) in sediments, although the extent of this role has yet to be quanti-

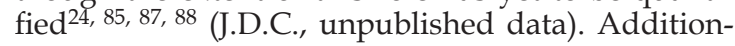
ally, enzymatic Fe(III) reduction is not limited to the Proteobacteria. The potential of the poorly described Acidobacteria to contribute to Fe(III) reduction was demonstrated with the isolation of Geothrix fermentans ${ }^{89}$ and supported by the identification of $16 \mathrm{~S}$ rDNA gene sequences most similar to this microorganism in an analysis of subsurface sediments. ${ }^{90}$ So far, the exact metabolic role of members of this phylum in the environment remains elusive because of the limited availability of pure cultures. However, given that Acidobacteria are ubiquitous in the environment, ${ }^{91,92}$ the contribution of these microorganisms to iron biogeochemical cycling in soils and sediments could be globally significant.

In addition to the FRM described above, which rely on energy conservation for growth from the dissimilatory reduction of Fe(III), various fermentative microorganisms have also been recognized to catalyse the enzymatic reduction of Fe(III) (References $93 \& 94$ and references therein). These fermentative microorganisms transfer only a minor fraction, approximately $5 \%$, of the available reducing equivalents to Fe(III) (Reference 94), and Fe(III) is not required for growth. The diversion of reducing equivalents to $\mathrm{Fe}(\mathrm{III})$ might provide an energetic advantage, utilizing the oxidation of $\operatorname{NAD}(\mathrm{P})$ $\mathrm{H}$ coupled to $\mathrm{Fe}(\mathrm{III})$ reduction to yield ATP. ${ }^{95}$ As such, Fe(III) reduction coupled to fermentative metabolism is considered to have a minor role in iron geochemical cycling relative to respiratory $\mathrm{Fe}(\mathrm{III})$ reduction.

In addition to the fermentative microorganisms that have been identified that reduce Fe(III), some sulphate-reducing ${ }^{96,97}$ and methanogenic ${ }^{98}$ microorganisms are also capable of Fe(III) reduction without the demonstrated benefit of growth. Competition for available electron donors between microbial communities supporting these metabolisms has been implicated in the suppression of sulphate reduction and methanogenesis in sedimentary environments. ${ }^{99}$, 100 However, the direct enzymatic reduction of $\mathrm{Fe}(\mathrm{III})$, coupled to the oxidation of hydrogen by sulphate-reducing and methanogenic microorganisms, would directly inhibit sulphatereducing and methanogenic metabolisms at the
Eutrophic

Eutrophic waters are rich in minerals and organic nutrients.

\section{Oligotrophic environment} An environment that is relatively low in nutrients and cannot support much plant life.

Thermophilic An organism that grows optimally at temperatures ranging from $45-80^{\circ} \mathrm{C}$.

\section{Acidophilic} An organism that grows in an acid environment (<pH 6).

\section{Alkaliphilic} An organism that grows in an alkaline environment $(\mathrm{pH}$ 9-pH 11). 


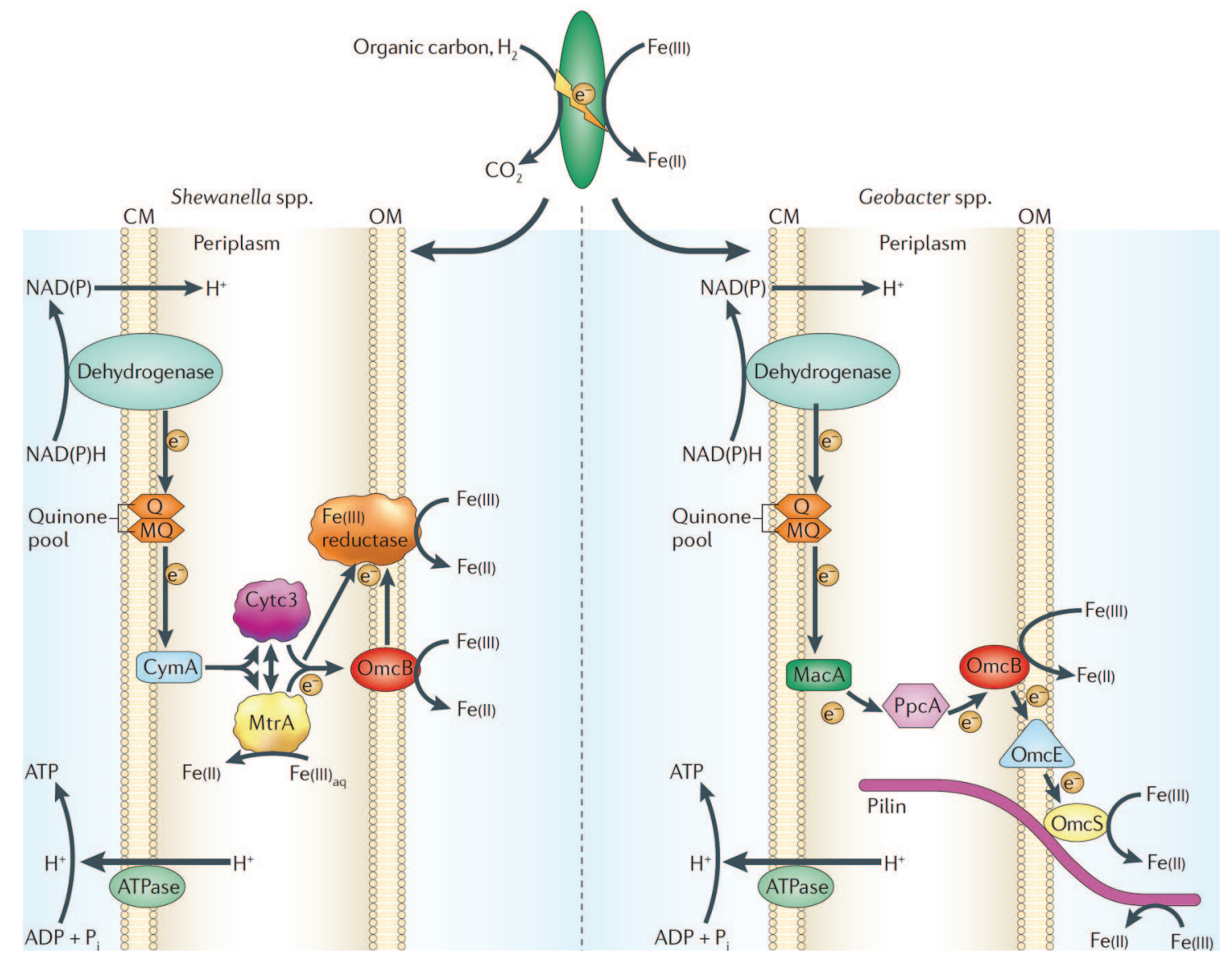

Figure 5. Physiological model of the biochemistry involved in microbial Fe(III) reduction by Shewanella and Geobacter spp. Full details of the model are given in the text. CM = cytoplasmic membrane; CymA = cytoplasmic-membrane-bound tetraheme $c$-type cytochrome; $C y t c 3=$ periplasmic $c$-type cytochrome; $\mathrm{e}^{-}=$electrons; MacA = cytoplasmic-membrane-bound cytochrome; $M Q=$ menaquinone; $M$ trA = periplasmic decaheme $c$-type cytochrome; OM = outer membrane; Omc = outer-membrane-bound cytochromes $B_{1} E_{1}$ and $S$ partially exposed on the cell surface; PpcA = a triheme periplasmic c-type cytochrome; $\mathrm{Q}=$ quinone.

cellular level. The physiological advantage created by coupling hydrogen oxidization to $\mathrm{Fe}(\mathrm{III})$ reduction is unknown. In fact, this metabolism would scavenge reducing equivalents, impairing the ability of these microorganisms to grow with the transfer of electrons to sulphate or carbon dioxide. The true ecological implications of this alternative lifestyle still remain a mystery.

Go with the flow: electron transport to $\mathrm{Fe}(\mathrm{III})$ oxides. Iron(III) oxide minerals are insoluble and so are unable to diffuse inside microbial cells. Therefore electron transport to the solid-phase terminal electron acceptor cannot occur in the periplasm as it does for soluble electron acceptors such as nitrate $^{101}$ or fumarate in the case of Shewanella frigidimarina. ${ }^{102}$ Instead, it would require the reduction of $\mathrm{Fe}(\mathrm{III})$ to occur outside the cell with a protein localized in the outer membrane, presumably a terminal iron reductase. Just as the strategies to utilize insoluble Fe(III) oxides as a terminal electron acceptor differ between the two model FRM, Shewanella spp. and Geobacter spp., the proteins involved in electron transport also differ. The only general sim- ilarity between the electron transport mechanisms involves the transfer of electrons from the dehydrogenase to a quinone pool consisting of ubiquinones and menaquinones in the cytoplasmic membrane to $c$-type cytochromes and finally to a reductase in the outer membrane $66,103,104,105,106$. Whereas a terminal iron reductase has so far eluded identification, significant developments have advanced our knowledge of $\mathrm{Fe}(\mathrm{III})$ reduction biochemistry in both model FRM.

The development of electron transport models is still in the formative stages as the number of $c$-type cytochromes directly implicated in $\mathrm{Fe}(\mathrm{III})$ reduction is far less than the number of $c$-type cytochromes that have been identified in completed genome sequences - the S. oneidensis and G. sulfurreducens genomes revealed 39 and 111 putative c-type cytochromes, respectively. ${ }^{107,} 108$ The high number of $c$ type cytochromes in G. sulfurreducens has led to the suggestion of the existence of multiple electrontransport pathways. ${ }^{109}$ The models depicted in Figure 5 illustrate the components known to be directly involved in electron transport to Fe(III) in both Shewanella spp. and Geobacter spp. so far. 
In Shewanella spp. the electrons are transferred from the menaquinone to a tetraheme $c$-type cytochrome, CymA, located in the cytoplasmic membrane. ${ }^{104,110,111}$ The electrons are then passed to electron carriers in the periplasm. Two c-type cytochromes in the periplasm have been identified so far as potential electron carriers necessary for Fe(III) reduction in Shewanella spp., MtrA and Cytc3 (References 112-114). Cytc3, a small tetraheme $c$-type cytochrome in the periplasm ${ }^{115}, 116$ might function as an electron shuttle between electron carriers ${ }^{117}$. MtrA is a decaheme $c$-type cytochrome that is similarly thought to accept electrons from the cytoplasmic membrane electron carrier CymA, and transfer these electrons to an outer membrane protein $(\mathrm{OMP})^{113}$. It has also been proposed that MtrA alternatively functions as a terminal reductase for soluble Fe(III) in the periplasm $^{114}$ (Figure 5). An outer membrane cytochrome partially exposed on the cell surface ${ }^{113,118}$, OmcB (formerly denoted as $\mathrm{MtrC}^{113}$ ), accepts electrons from periplasmic proteins and has the potential to reduce extracellular Fe(III) directly ${ }^{118}$ (Figure 5). This is supported by studies involving a mutation in omcB that resulted in a decreased ability to reduce Fe(III). However, some Fe(III) reduction did still occur ${ }^{119}$, indicating that Fe(III) reduction is not absolutely dependent on a functioning omcB (Figure 5).

Given the limited information available so far, the relationship between the periplasmic cytochromes and OMPs has not been firmly established in Geobacter spp. ${ }^{120}$ A key periplasmic cytochrome, MacA, was identified in the cytoplasmic membrane and shown to have a central role in the transfer of electrons to $\mathrm{Fe}(\mathrm{III})$. MacA is predicted to function as an intermediate carrier similarly to MtrA in Shewanella spp. ${ }^{120}$ and therefore might pass electrons to other periplasmic proteins such as PpcA, a tri-heme periplasmic c-type cytochrome involved in electron transport to OMPs ${ }^{121}$ (Figure 5). One such OMP, OmcB, was determined to have a significant role in Fe(III) reduction ${ }^{109,122}$. Disruptions in omcB by gene replacement impaired the ability of G. sulfurreducens to reduce Fe(III) by approximately $94-97 \%$ (Reference 122). However, the omcB-deficient mutant adapted to growth on soluble $\mathrm{Fe}(\mathrm{III})$ over time with similar reduction rates to the wild type, although growth was only approximately $60 \%$ of the wild type ${ }^{109}$. Interestingly, the adapted mutant was unable to reduce insoluble Fe(III) oxides, indicating that different electron transport mechanisms are used to reduce insoluble and soluble Fe(III) sources ${ }^{109}$. The recent identification of conductive 'nanowires' implicated the involvement of other OMPs in electron transport to Fe(III) oxides. Reguera et al. ${ }^{63}$ have proposed that pili directly accept electrons from intermediary electron-transfer proteins located in the periplasm and/or outer membrane for transfer to the solidphase Fe(III) oxide surface (Figure 5). In contrast to the appendages identified in S. oneidensis ${ }^{64}$, redoxreactive structures have not been identified on the conductive pili observed in Geobacter spp. ${ }^{63}$ The conductive nature of these pilin structures remains a mystery and introduces an exciting new twist to cell biology.

\section{Box 2. Biotechnological applications}

\section{Heavy-metal and radionuclide immobilization}

The end products of anaerobic microbial oxidation of Fe(II) can also affect the geochemistry of contaminants through the formation of various environmentally relevant $\mathrm{Fe}(\mathrm{III})$-bearing minerals that can regulate contaminant solubility in natural environments, ${ }^{5,22,43}$ such as ferric oxyhydroxide, goethite, hematite, iron hydrogen carbonate or maghemite. 4, 24, 40, 47 The precipitation of these biogenic Fe(III) oxides provides a mechanism for the immobilization of heavy metals and metalloids through co-precipitation or physical envelopment, and provides a reactive surface with an adsorptive affinity for anions (that is, $\mathrm{PO}_{4}{ }^{3-}$ ) and cations (that is, $\mathrm{Zn}(\mathrm{II}), \mathrm{As}(\mathrm{V}), \mathrm{Co}(\mathrm{II})$ and $\mathrm{U}(\mathrm{vi}))$ (References 5,22$)$. Heavy metals and radionuclides including $\mathrm{U}(\mathrm{VI})$ are rapidly removed from solution during anaerobic nitrate-dependent microbial Fe(II) oxidation in association with the biogenic Fe(III) oxides. ${ }^{5}$ As such, the anaerobic formation of biogenic Fe(III)-oxide-containing minerals has been identified as a plausible bioremediative strategy for permanently immobilizing heavy metals and radionuclides. ${ }^{5,137}$

\section{Energy generation and contaminant immobilization or degradation} An electrode is another solid-phase electron acceptor used by Fe(II)-reducing microorganisms (FRM) that we can exploit to our energetic advantage. The harvest of electrical energy mediated by FRM in sediments and microbial fuel cells is a technological reality. $4,138,139,140,141,142$ The utilization of electrodes as an electron acceptor has not only been proposed to harvest energy from sediments but also to remediate environments contaminated with biodegradable organic compounds, such as mono- and polycyclic-aromatic hydrocarbons ${ }^{141}$, potentially harvesting energy in the process. FRM are not only capable of generating electricity, previous studies have indicated an incredible metabolic versatility and these organisms have been demonstrated to transform various organic (that is, benzene, toluene, phenol and chlorinated compounds) ${ }^{90,143,144,145,146}$ and heavy metal or radionuclide contaminants (that is, uranium, technetium and chromium). ${ }^{55,147,148}$

\section{Concluding remarks}

Over the past two decades, recognition of the microbial reduction and oxidation of the fourth most abundant element in the Earth's crust has identified a globally significant biogeochemical process. Although it is recognized that the microorganisms involved in these competing metabolisms are ubiquitous, the physiology of microbial $\mathrm{Fe}(\mathrm{III})$ reduction and $\mathrm{Fe}(\mathrm{II})$ oxidation remains an enigma, as a terminal Fe(III) reductase has yet to be identified and nothing apart from the implicated role of $c$-type cytochrome(s) is known of $\mathrm{Fe}(\mathrm{II})$ oxidation at circumneutral $\mathrm{pH}$. Genome sequencing and the subsequent development of in silico physiological models can be used to predict microbial metabolism in particular environmental conditions ${ }^{123}, 124$, and can potentially provide greater insight into microbially mediated iron oxidation and reduction reactions in environmental systems. These advances can also be applied to enhance and predict the behaviour of microorganisms exploited for their metabolism associated with biotechnological applications (Box 2). Although significant advances have been made, we are continuously learning of previously unknown microbially mediated iron redox reactions in diverse environments and searching for microorganisms responsible for catalysing these unique metabolisms. A topical example of this is the recently identified anaerobic oxidation of ammonium coupled to dissimilatory $\mathrm{Fe}(\mathrm{III})$ reduction $^{8}$ for which no organism has yet been identified. As these sorts of discoveries are made, the true ubiquity and diversity of the organisms involved in iron biogeochemistry will be uncovered. Because of the geological and geochemical importance of iron on a global scale, the activity of these organisms shapes the world we live in today. 


\section{References}

1. Cornell, R. M. \& Schwertmann, U. The Iron Oxides: Structure, Properties, Reactions, Occurrences and Uses (Wiley-VCH, Weinheim, 2003).

2. Stumm, W. \& Morgan, J. J. Aquatic Chemistry: Chemical Equilibria and Rates in Natural Waters (John Wiley \& Sons, New York, 1996).

3. Baker, B. J. \& Banfield, J. F. Microbial communities in acid mine drainage. FEMS Microbiol. Ecol. 44, 139-152 (2003).

4. Chaudhuri, S. K., Lack, J. G. \& Coates, J. D. Biogenic magnetite formation through anaerobic biooxidation of Fe(II). Appl. Environ. Microbiol. 67, 2844-2848 (2001)

This paper gives the first demonstration of magnetite formation through anaerobic iron bio-oxidation and the first demonstration of the bioavailability of Fe(II) in silicaceous minerals.

5. Lack, J. G. et al. Immobilization of radionuclides and heavy metals through anaerobic bio-oxidation of Fe(II). Appl. Environ. Microbiol. 68, 27042710 (2002).

6. Lovley, D. R., Holmes, D. E. \& Nevin, K. P. Dis similatory $\mathrm{Fe}(\mathrm{III})$ and $\mathrm{Mn}$ (IV) reduction. Adv. Microb. Physiol. 49, 219-286 (2004).

7. Canfield, D. E. et al. Pathways of organic carbon oxidation in three continental margin sediments. Mar. Geol. 113, 27-40 (1993).

This paper gives the first demonstration of the importance of microbial Fe(III) reduction for the oxidation of organic matter in marine sediments.

8. Clement, J., Shrestha, J., Ehrenfeld, J. \& Jaffe, P. Ammonium oxidation coupled to dissimilatory reduction of iron under anaerobic conditions in wetland soils. Soil Biol. Biochem. 37, 2323-2328 (2005)

9. Lovley, D. R. Dissimilatory Fe(III) and Mn(IV) reduction. Microbiol. Rev. 55, 259-287 (1991)

10. Kukkadapu, R. K., Zachara, J. M., Smith, S. C. Fredrickson, J. K. \& Liu, C. X. Dissimilatory bacterial reduction of Al-substituted goethite in subsurface sediments. Geochim. Cosmochim Acta 65, 2913-2924 (2001).

11. Mendelssohn, I. A., Kleiss, B. A. \& Wakeley, J. S. Factors controlling the formation of oxidized root channels. Wetlands 15, 37-46 (1995).

12. Furukawa, Y., Smith, A. C., Kostka, J. E., Watkins, J. \& Alexander, C. R. Quantification of macrobenthic effects on diagenesis using a multicomponent inverse model in salt marsh sediments. Limnol. Oceanogr. 49, 2058-2072 (2004)

13. Emerson, D., Weiss, J. V. \& Megonigal, J. P. Ironoxidizing bacteria are associated with ferric hy droxide precipitates (Fe-plaque) on the roots of wetland plants. Appl. Environ. Microbiol. 65, 2758-2761 (1999)

14. Weiss, J. V., Emerson, D., Backer, S. M. \& Megonigal, J. P. Enumeration of Fe(II)-oxidizing and Fe(III)-reducing bacteria in the root zone of wetland plants: Implications for a rhizosphere iron cycle. Biogeochemistry 64, 77-96 (2003).

15. Weiss, J. V., Emerson, D. \& Megonigal, J. P. Rhizosphere iron(III) deposition and reduction in a Juncus effusus L.-dominated wetland. Soil Sci. Soc. Am. J. 69, 1861-1870 (2005)

16. Ghiorse, W. C. Biology of iron-depositing and manganese-depositing bacteria. Ann. Rev. Microbiol. 38, 515-550 (1984).

17. Emerson, D. \& Moyer, C. L. Isolation and characterization of novel iron-oxidizing bacteria that grow at circumneutral pH. Appl. Environ. Microbiol. 63, 4784-4792 (1997).

This paper demonstrates the unsuspected ubiquity and diversity of organisms capable of microaerophilic Fe(II) bio-oxidation at circumneutral pH.

18. Sobolev, D. \& Roden, E. E. Suboxic deposition of ferric iron by bacteria in opposing gradients of $\mathrm{Fe}(\mathrm{II})$ and oxygen at circumneutral $\mathrm{pH}$. Appl. Environ. Microbiol. 1328-1334 (2001).
19. Edwards, K. J., Rogers, D. R., Wirsen, C. O. \& McCollom, T. M. Isolation and characterization of novel psychrophilic, neutrophilic, Fe-oxidizing, chemolithoautotrophic $\alpha$ - and $\gamma$-Proteobacteria from the deep sea. Appl. Environ. Microbiol. 69, 2906-2913 (2003).

20. Widdel, F. et al. Ferrous iron oxidation by anoxygenic phototrophic bacteria. Nature 362 , 834836 (1993).

This paper gives the first demonstration of anaerobic, phototrophic Fe(II) oxidation and suggests the importance of this metabolism in the Earth's early history.

21. Straub, K. L., Benz, M., Schink, B. \& Widdel, F. Anaerobic, nitrate-dependent microbial oxidation of ferrous iron. Appl. Environ. Microbiol. 62, 1458-1460 (1996).

This paper gives the first clear demonstration of anaerobic, mesophilic nitrate-dependent $\mathrm{Fe}$ (II) oxidation.

22. Senn, D. B. \& Hemond, H. F. Nitrate controls on iron and arsenic in an urban lake. Science 296, 2373-2376 (2002).

23. Straub, K. L., Schonhuber, W., Buchholz-Cleven, B. \& Schink, B. Diversity of ferrous iron-oxidizing, nitrate-reducing bacteria and their involvement in oxygen-independent iron cyclinG. Geomicrobiol. J. 21, 371-378 (2004)

24. Weber, K. A., Urrutia, M. M., Churchill, P. F., Kukkadapu, R. K. \& Roden, E. E. Anaerobic redox cycling of iron by freshwater sediment microorganisms. Environ. Microbiol. 8, 100-113 (2006)

25. Weber, K. A., Picardal, F. W. \& Roden, E. E. Microbially catalyzed nitrate-dependent oxidation of biogenic solid-phase Fe(II) compounds. Environ. Sci. Technol. 35, 1644-1650 (2001).

26. Bruce, R. A., Achenbach, L. A. \& Coates, J. D. Reduction of (per)chlorate by a novel organism isolated from paper mill waste. Environ. Microbiol. 1, 319-329 (1999).

27. Shelobolina, E. S., VanPraagy, C. G. \& Lovley, D. $R$. Use of ferric and ferrous iron containing min erals for respiration by Desulfitobacterium frappieri. Geomicrobiol. J. 20, 143-156 (2003).

28. Harrison Jr, A. P. The acidophilic Thiobacilli and other acidophilic bacteria that share their habitaT. Ann. Rev. Microbiol. 38, 265-292 (1984).

29. Davison, W. \& Seed, G. The kinetics of the oxidation of ferrous iron in synthetic and natura waters. Geochim. Cosmochim. Acta 47, 67-79 (1983).

30. Emerson, D. \& Weiss, J. V. Bacterial iron oxidation in circumneutral freshwater habitats: find ings from the field and the laboratory. Geomicrobiol. J. 21, 405-414 (2004).

31. Hafenbradl, D. et al. Ferroglobus placidus gen. nov., sp. nov. a novel hyperthermophilic archaeum that oxidizes Fe(II) at neutral $\mathrm{pH}$ under anoxic conditions. Arch. Microbiol. 166, 308314 (1996).

This paper describes the first isolation of a hyperthermophilic anaerobic, nitrate-dependent Fe(II)-oxidizing organism and the only archaeum known to be capable of this metabolism.

32. Jiao, Y., Kappler, A., Croal, L. R. \& Newman, D. $\mathrm{K}$. Isolation and characterization of a genetically tractable photoautotrophic Fe(II)-oxidizing bacterium, Rhodopseudomonas palustris strain TIE-1. Appl. Environ. Microbiol. 71 4487-4496 (2005).

33. Ehrenreich, A. \& Widdel, F. Anaerobic oxidation of ferrous iron by purple bacteria, a new type of phototrophic metabolism. Appl. Environ. Microbiol. 60, 4517-4526 (1994).

34. Heising, S. \& Schink, B. Phototrophic oxidation of ferrous iron by a Rhodomicrobium vannielii strain. Microbiology 144, 2263-2269 (1998).

35. Heising, S., Richter, L., Ludwig, W. \& Schink, B. Chlorobium ferrooxidans sp. nov., a phototrophic green sulfur bacterium that oxidizes iron in coculture with a 'Geospirillum' sp. strain. Arch. Microbiol. 172, 116-124 (1999).

36. Straub, K. L., Rainey, F. A. \& Widdel, F. Rhodovu- lum iodosum sp. nov, and Rhodovulum robiginosum sp. nov., two new marine phototrophic ferrous-iron-oxidizing purple bacteria. InT. J. SysT. Bacteriol. 49, 729-735 (1999).

37. Straub, K. L., Benz, M. \& Schink, B. Iron metabo lism in anoxic environments at near neutral $\mathrm{pH}$. FEMS Microbiol. Ecol. 34, 181-186 (2001).

38. Kappler, A. \& Newman, D. K. Formation of $\mathrm{Fe}$ (III)-minerals by Fe(II)-oxidizing photoautotrophic bacteria. Geochim. Cosmochim. Acta 68, 1217-1226 (2004).

39. Ciania, A., Gossa, K.-U. \& Schwarzenbach, R. P. Light penetration in soil and particulate minerals. Eur. J. Soil Sci. 53, 561-574 (2005).

40. Straub, K. L., Hanzlik, M. \& Buchholz-Cleven, B. E. E. The use of biologically produced ferrihydrite for the isolation of novel iron-reducing bacteria. SysT. Appl. Microbiol. 21, 442-449 (1998).

41. Kluber, H. D. \& Conrad, R. Effects of nitrate, nitrite, $\mathrm{NO}$ and $\mathrm{N}_{2} \mathrm{O}$ on methanogenesis and other redox processes in anoxic rice field soil. FEMS Microbiol. Ecol. 25, 301-318 (1998).

42. Ratering, S. \& Schnell, S. Nitrate-dependent iron(II) oxidation in paddy soil. Environ. Microbiol. 3, 100-109 (2001)

43. Finneran, K. T., Housewright, M. E. \& Lovley, D. R. Multiple influences of nitrate on uranium solubility during bioremediation of uranium-contaminated subsurface sediments. Environ. Microbiol. 4, 510-516 (2002).

44. Weber, K. A. \& Coates, J. D. in Manual of Environmental Microbiology, 3rd edn (eds Hurst, C. J., Crawford, R. L., Knudsen, G. R., McInerney, M J. \& Stetzenbach, L. D.) in the press (ASM Press)

45. Weber, K. A. et al. Anaerobic nitrate-dependent iron(II) bio-oxidation by a novel, lithoautotrophic, $\beta$-proteobacterium, strain 2002. Appl. Environ. Microbiol. 72, 686-694 (2006).

The first description of the only organism that has been clearly demonstrated to grow by mesophilic autotrophic nitrate-dependent $\mathrm{Fe}$ (II) oxidation.

46. Beller, H. R. Anaerobic, nitrate-dependent oxidation of U(IV) oxide minerals by the chemolithoautotrophic bacterium Thiobacillus denitrificans. Appl. Environ. Microbiol. 71, 2170-2174 (2005).

47. Lack, J. G., Chaudhuri, S. K., Chakraborty, R. Achenbach, L. A. \& Coates, J. D. Anaerobic biooxidation of $\mathrm{Fe}$ (II) by Dechlorosoma suillum. Mi crob. Ecol. 43, 424-431 (2002).

48. Coates, J. D. \& Achenbach, L. A. Microbial perchlorate reduction: rocket-fuelled metabolism Nature Rev. Microbiol. 2, 569-580 (2004).

49. Vorholt, J. A., Hafenbradl, D., Stetter, K. O. \& Thauer, R. K. Pathways of autotrophic $\mathrm{CO}_{2}$ fixation and dissimilatory nitrate reduction to $\mathrm{N}_{2} \mathrm{O}$ in Ferroglobus placidus. Arch. Microbiol. 167, 19-23 (1997)

50. Gold, T. The deep, hot biosphere. Proc. Natl Acad. Sci. USA 89, 6045-6049 (1992).

51. Cairns-Smith, A. G. Precambrian solution photochemistry, inverse segregation, and banded iron formations. Nature 276, 807-808 (1978).

52. Vargas, M., Kashefi, K., Blunt-Harris, E. L. \& Lovley, D. R. Microbiological evidence for Fe(III) reduction on early Earth. Nature 395, 65-67 (1998).

Describes the first demonstration of dissimilatory $\mathrm{Fe}(\mathrm{III})$ reduction by hyperthermophilic Archaea.

53. Lovley, D. R. in Origins: Genesis, Evolution and Diversity of Life (ed. Seckbach, J.) 707 (Kluwer Dordrecht, Boston, 2004).

54. Kashefi, K. \& Lovley, D. R. Extending the upper temperature limit for life. Science 301, 934 (2003)

Provides a description of the most heat-tolerant organism known, strain 121, which grows at $121^{\circ} \mathrm{C}$

55. Kashefi, K. \& Lovley, D. Reduction of Fe(III), $\mathrm{Mn}(\mathrm{IV})$, and toxic metals at 100 degrees $\mathrm{C}$ by Pyrobaculum islandicum. Appl. Environ. Micro- 
biol. 66, 1050-1056 (2000)

56. Tor, J. M., Kashefi, K. \& Lovley, D. R. Acetate oxidation coupled to $\mathrm{Fe}$ (III) reduction in hyperthermophilic microorganisms. Appl. Environ. Microbiol. 67, 1363-1365 (2001).

57. Kostka, J. E., Stucki, J. W., Nealson, K. H. \& Wu, J. Reduction of structural Fe(III) in smectite by a pure cultrue of Shewanella putrefaciens strain MR-1. Clays Clay Miner. 44, 522-529 (1996). This paper gives the first demonstration that structural Fe(III) in clay minerals is bioavailable for dissimilatory microbial Fe(III) reduction.

58. Kostka, J. E. \& Nealson, K. H. Dissolution and reduction of magnetite by bacteria. Environ. Sci. Technol. 29, 2535-2540 (1995)

59. Fredrickson, J. K. et al. Biogenic iron mineralization accompanying the dissimilatory reduction of hydrous ferric oxide by a groundwater bacterium. Geochim. Cosmochim. Acta 62, 32393257 (1998).

60. Glasauer, S., Weidler, P. G., Langley, S. \& Beveridge, T. J. Controls on Fe reduction and mineral formation by a subsurface bacterium. Geochim. Cosmochim. Acta 67, 1277-1288 (2003).

61. Nevin, K. P. \& Lovley, D. R. Lack of production of electron-shuttling compounds or solubilization of $\mathrm{Fe}$ (III) during reduction of insoluble $\mathrm{Fe}$ (III) oxide by Geobacter metallireducens. Appl. Environ. Microbiol. 66, 2248-2251 (2000).

62. Childers, S. E., Ciufo, S. \& Lovley, D. R. Geobacter metallireducens accesses insoluble $\mathrm{Fe}$ (III) oxide by chemotaxis. Nature $416,767-769$ (2002).

63. Reguera, G. et al. Extracellular electron transfer via microbial nanowires. Nature 435, 10981101 (2005)

Provides the first description of the nanowire concept involved in the transfer of electrons onto insoluble electron acceptors during microbial respiration.

64. Gorby, Y. A. et al. Electrically conductive bacterial nanowires produced by Shewanella oneidensis strain MR-1 and other microorganisms. Proc. Natl. Acad. Sci. USA 103, 11358-11363 (2006).

65. Lovley, D. R., Coates, J. D., Blunt-Harris, E. L., Phillips, E. J. P. \& Woodward, J. C. Humic substances as electron acceptors for microbial respiration. Nature 382, 445-448 (1996).

This paper provides the first demonstration that bacteria can mediate the reduction of insoluble electron acceptors through the use of redox-active natural organic matter.

66. Newman, D. K. \& Kolter, R. A role for excreted quinones in extracellular electron transfer. $\mathrm{Na}$ ture 405, 94-97 (2000)

67. Nevin, K. P. \& Lovley, D. R. Mechanisms for accessing insoluble $\mathrm{Fe}$ (III) oxide during dissimilatory Fe(III) reduction by Geothrix fermentans. Appl. Environ. Microbiol. 68, 2294-2299 (2002)

68. Turick, C. E., Tisa, L. S. \& Caccavo, F. Melanin production and use as a soluble electron shuttle for $\mathrm{Fe}(\mathrm{III})$ oxide reduction and as a terminal electron acceptor by Shewanella algae Bry. Appl. Environ. Microbiol. 68, 2436-2444 (2002)

69. Nevin, K. P. \& Lovley, D. R. Potential for nonenzymatic reduction of $\mathrm{Fe}$ (III) via electron shuttling in subsurface sediments. Environ. Sci. Technol. 34, 2472-2478 (2000).

70. Hernandez, M. E., Kappler, A. \& Newman, D. K. Phenazines and other redox-active antibiotics promote microbial mineral reduction. Appl. Environ. Microbiol. 70, 921-928 (2004)

71. Hernandez, M. E. \& Newman, D. K. Extracellula electron transfer. Cell. Mol. Life Sci. 58, 15621571 (2001).

72. Nevin, K. P. \& Lovley, D. R. Mechanisms for $\mathrm{Fe}(\mathrm{III})$ oxide reduction in sedimentary environments. Geomicrobiol. J. 19, 141-159 (2002).

73. Lovley, D. R., Fraga, J. L., Coates, J. D. \& BluntHarris, E. L. Humics as an electron donor for anaerobic respiration. Environ. Microbiol. 1, 89-98 (1999).
74. Coates, J. D., Cole, K. A., Chakraborty, R. O'Connor, S. M. \& Achenbach, L. A. The diversity and ubiquity of bacteria utilizing humic substances as an electron donor for anaerobic respiration. Appl. Environ. Microbiol. 68, 24452452 (2002).

75. Roh, Y. et al. Isolation and characterization of metal-reducing Thermoanaerobacter strains from deep subsurface environments of the Piceance Basin, Colorado. Appl. Environ. Microbiol. 68, 6013-6020 (2002).

76. Bowman, J. P. et al. Shewanella gelidimarina $\mathrm{sp}$. nov. and Shewanella frigidimarina sp. nov., novel Antarctic species with the ability to produce eicosapentaenoic acid (20:5 omega 3) and grow anaerobically by dissimilatory Fe(III) reduction. InT. J. SysT. Bacteriol. 4, 1040-1047 (1997).

77. Kusel, K., Dorsch, T., Acker, G. \& Stackebrandt, E. Microbial reduction of $\mathrm{Fe}$ (III) in acidic sediments: isolation of Acidiphilium cryptum JF-5 capable of coupling the reduction of Fe(III) to the oxidation of glucose. Appl. Environ. Microbiol. 65, 3633-3640 (1999).

78. Ye, Q. et al. Alkaline anaerobic respiration: Isolation and characterization of a novel alkaliphilic and metal-reducing bacterium. Appl. Environ. Microbiol. 70, 5595-5602 (2004).

79. Gorlenko, V. et al. Anaerobranca californiensis sp nov., an anaerobic, alkalithermophilic, fermentative bacterium isolated from a hot spring on Mono Lake. InT. J. SysT. Evol. Microbiol. 54, 739-743 (2004)

80. Myers, C. R. \& Nealson, K. H. Bacterial manganese reduction and growth with manganese oxide as the sole electron-acceptor. Science 240, 1319-1321 (1988).

81. Caccavo F. Jr, Blakemore, R. P. \& Lovely, D. R A hydrogen-oxidizing, $\mathrm{Fe}$ (III)-reducing microorganism from the Great Bay Estuary, New Hampshire. Appl. Environ. Microbiol. 58, 32113216 (1992).

82. Zachara, J. M. et al. Bacterial reduction of crystalline Fe(III) oxides in single phase suspensions and subsurface materials. Am. Mineral. 83, 1426-1443 (1998).

83. Stein, L., La Duc, M., Grundl, T. \& Nealson, K. Bacterial and archaeal populations associated with freshwater ferromanganous micronodules and sediments. Environ. Microbiol. 3, 10-18 (2001).

84. Snoeyenbos-West, O. L., Nevin, K. P., Anderson, R. T. \& Lovley, D. R. Enrichment of Geobacter species in response to stimulation of Fe(III) reduction in sandy aquifer sediments. Microb. Ecol. 39, 153-167 (2000).

85. Roling, W., van Breukelen, B., Braster, M., Lin, B \& van Verseveld, H. Relationships between microbial community structure and hydrochemistry in a landfill leachate-polluted aquifer. Appl. Envir. Microbiol. 67, 4619-4629 (2001)

86. Todorova, S. G. \& Costello, A. M. Design of Shewanella specific 16S rRNA primers and application to analysis of Shewanella in a minerotrophic wetland. Environ. Microbiol. 8, 426-432 (2006).

87. Cummings, D., Caccavo, F., Spring, S. \& Rosenzweig, R. Ferribacterium limneticum, gen. nov., sp. nov., an Fe(III)-reducing microorganism isolated from mining-impacted freshwate lake sediments. Arch. Microbiol. 171, 183-188 (1999).

88. Finneran, K., Johnsen, C. \& Lovley, D. Rhodoferax ferrireducens sp nov., a psychrotolerant, facultatively anaerobic bacterium that oxidizes acetate with the reduction of Fe(III). InT. J. SysT. Evol. Microbiol. 53, 669-673 (2003).

89. Coates, J. D., Ellis, D. J., Gaw, C. V. \& Lovley, D. R. Geothrix fermentans gen. nov. sp. nov. a novel $\mathrm{Fe}$ (III)-reducing bacterium from a hydrocarbon contaminated aquifer. InT. J. SysT. Bacteriol. 49 1615-1622 (1999).

90. Anderson, R. T., Rooney-Varga, J. N., Gaw, C. V. \& Lovely, D. R. Anaerobic benzene oxidation in the Fe(III) reduction zone of petroleum-contaminated aquifers. Environ. Sci. Technol. 32, 1222-1229 (1998)

91. Hugenholtz, P., Goebel, B. M. \& Pace, N. R. Impact of culture-independent studies on the emerging phylogenetic view of bacterial diversity. J. Bacteriol. 180, 4765-4774 (1998).

92. Barns, S. M., Takala, S. L. \& Kuske, C. R. Wide distribution and diversity of members of the bacterial kingdom Acidobacterium in the environmenT. Appl. Environ. Microbiol. 65, 17311737 (1999).

93. Roberts, J. L. Reduction of ferric hydroxide by strains of Bacillus polymyxa. Soil Sci. 63, 135140 (1947).

94. Lovley, D. R. \& Phillips, E. J. P. Organic matter mineralization with reduction of ferric iron in anaerobic sediments. Appl. Environ. Microbiol. 51, 683-689 (1986).

95. Dobbin, P. S. et al. Dissimilatory Fe(III) reduction by Clostridium beijerinckii isolated from freshwater sediment using Fe(III) maltol enrichmenT. FEMS Microbiol. LetT. 176, 131-138 (1999).

96. Coleman, M. L., Hedrick, D. B., Lovley, D. R. White, D. C. \& Pye, K. Reduction of Fe(III) in sediments by sulphate-reducing bacteria. $\mathrm{Na}$ ture 361, 436-438 (1993).

97. Lovley, D. R., Roden, E. E., Phillips, E. J. P. \& Woodward, J. C. Enzymatic iron and uranium reduction by sulfate-reducing bacteria. Mar. Geol. 113, 41-53 (1993).

98. Bond, D. R. \& Lovley, D. Reduction of Fe(III) oxide by methanogens in the presence and absence of extracellular quinones. Environ. Microbiol. 4, 115-124 (2002).

99. Lovley, D. \& Phillips, E. Competitive mechanisms for inhibition of sulfate reduction and methane production in the zone of ferric iron reduction in sediments. Appl. Environ. Microbiol. 53, 2636-2641 (1987).

100. Roden, E. E. \& Wetzel, R. G. Organic carbon oxidation and supression of methane production by microbial Fe(III) oxide reduction in vegetated and unvegetated freshwater wetland sediments. Limnol. Oceanogr. 41, 1733-1748 (1996).

101. Madigan, M. T., Martinko, J. M. \& Parker, J. Brock Biology of Microorganisms (Pearson Education, New Jersey, 2002).

102. Reid, G. A. et al. Structure and function of flavocytochrome $\mathrm{c}(3)$, the soluble fumarate reductase from Shewanella NCIMB400. Biochem. Soc. Trans. 26, 418-421 (1998).

103. Lovley, D. R. et al. Geobacter metallireducens gen. nov. sp. nov., a microorganism capable of coupling the complete oxidation of organiccompounds to the reduction of iron and other metals. Arch. Microbiol. 159, 336-344 (1993).

104. Myers, C. R. \& Myers, J. M. Role of menaquinone in the reduction of fumarate, nitrate, iron(III) and manganese(IV) by Shewanella putrefaciens Mr-1. FEMS Microbiol. LetT. 114, 215222 (1993).

105. Saffarini, D. A., Blumerman, S. L. \& Mansoorabadi, K. J. Role of menaquinones in Fe(III) reduction by membrane fractions of Shewanella putrefaciens. J. Bacteriol. 184, 846-848 (2002).

106. Myers, C. R. \& Myers, J. A. Shewanella oneidensis MR-1 restores menaquinone synthesis to a menaquinone-negative mutanT. Appl. Environ. Microbiol. 70, 5415-5425 (2004).

107. Heidelberg, J. F. et al. Genome sequence of the dissimilatory metal ion-reducing bacterium Shewanella oneidensis. Nature Biotechnol. 20, 1118-1123 (2002).

108. Methe, B. A. et al. Genome of Geobacter sulfurreducens: metal reduction in subsurface environments. Science 302, 1967-1969 (2003).

109. Leang, C. et al. Adaptation to disruption of the electron transfer pathway for Fe(III) reduction in Geobacter sulfurreducens. J. Bacteriol. 187, 5918-5926 (2005).

110. Myers, C. R. \& Myers, J. M. Cloning and sequence of cymA a gene encoding a tetra- 
heme cytochrome $c$ required for reduction of iron(III), fumarate, and nitrate by Shewanella putrefaciens MR-1. J. Bacteriol. 179, 1143-1152 (1997).

111. Myers, J. M. \& Myers, C. R. Role of the tetraheme cytochrome CymA in anaerobic electron transport in cells of Shewanella putrefaciens MR-1 with normal levels of menaquinone. J. Bacteriol. 182, 67-75 (2000).

112. Beliaev, A. S. \& Saffarini, D. A. Shewanella putrefaciens $m$ tr $B$ encodes an outer membrane protein required for Fe(III) and $\mathrm{Mn}(\mathrm{IV})$ reduction. J. Bacteriol. 180, 6292-6297 (1998).

113. Beliaev, A. S., Saffarini, D. A., McLaughlin, J. L. \& Hunnicutt, D. MtrC, an outer membrane decahaem $c$ cytochrome required for metal reduction in Shewanella putrefaciens MR-1. Mol. Microbiol. 39, 722-730 (2001).

114. Pitts, K. E. et al. Characterization of the Shewanella oneidensis MR-1 decaheme cytochrome MtrA. J. Biol. Chem. 278, 27758-27765 (2003).

115. Dobbin, P. S., Butt, J. N., Powell, A. K., Reid, G. A \& Richardson, D. J. Characterization of a flavocytochrome that is induced during the anaerobic respiration of $\mathrm{Fe}(\mathrm{III})$ by Shewanella frigidimarina NCIMB400. Biochem. J. 342, 439-448 (1999).

116. Gordon, E. H. J. et al. Identification and characterization of a novel cytochrome c(3) from Shewanella frigidimarina that is involved in Fe(III) respiration. Biochem. J. 349, 153-158 (2000).

117. Leys, D. et al. Crystal structures at atomic resolution reveal the novel concept of 'electronharvesting' as a role for the small tetraheme cytochrome c. J. Biol. Chem. 277, 35703-35711 (2002).

118. Myers, C. R. \& Myers, J. M. Cell surface exposure of the outer membrane cytochromes of Shewanella oneidensis MR-1. LetT. Appl. Microbiol. 37, 254-258 (2003).

119. Myers, J. M. \& Myers, C. R. Overlapping role of the outer membrane cytochromes of Shewanella oneidensis MR-1 in the reduction of manganese(IV) oxide. LetT. Appl. Microbiol. 37 21-25 (2003).

120. Butler, J. E., Kaufmann, F., Coppi, M. V., Nunez, C. \& Lovley, D. R. MacA a diheme c-type cytochrorne involved in Fe(III) reduction by $\mathrm{Geo}$ bacter sulfurreducens. J. Bacteriol. 186, 40424045 (2004).

121. Lloyd, J. R. et al. Biochemical and genetic characterization of PpcA, a periplasmic c-type cytochrome in Geobacter sulfurreducens. Biochem. J. 369, 153-161 (2003).

122. Leang, C., Coppi, M. V. \& Lovley, D. R. OmcB, a c-type polyheme cytochrome, involved in $\mathrm{Fe}(\mathrm{III})$ reduction in Geobacter sulfurreducens. J. Bacteriol. 185, 2096-2103 (2003).

123. Lovely, D. Cleaning up with genomics: applying molecular biology to bioremediation. Nature Rev. Microbiol. 1, 35-44 (2003).

124. Mahadevan, R. et al. Characterization of metabolism in the Fe(III)-reducing organism Geobacter sulfurreducens by constraint-based mod elinG. Appl. Environ. Microbiol. 72, 1558-1568 (2006).

125. Cloud, P. E. Paleoecological significance of the banded iron-formation. Econ. Geol. 68, 11351143 (1973).
126. Braterman, P. S., Cairns-Smith, A. G. \& Sloper, R. W. Photo-oxidation of hydrated Fe(II) - significance for banded iron formations. Nature 303. 163-164 (1983)

127. Cloud, P. E. Significance of the Gunflint (Precambrian) microflora. Science 148, 27-35 (1965).

128. Lovley, D. R., Stolz, J. F., Nord, G. L. \& Phillips, E. J. P. Anaerobic production of magnetite by a dissimilatory iron-reducing microorganism. Nature 330, 252-254 (1987).

This paper gives the first demonstration of extracellular biogenic magnetite formation.

129. Kohnauser, K. O. et al. Could bacteria have formed the Precambrian banded iron formations? Geology 20, 1079-1082 (2002).

130. Kappler, A., Pasquero, C., Konhauser, K. O. \& Newman, D. K. Deposition of banded iron formations by anoxygenic phototrophic Fe(II)-oxidizing bacteria. Geology 33, 865-868 (2005).

131. Holm, N. G. The ${ }^{13} \mathrm{C} /{ }^{12} \mathrm{C}$ ratios of siderite and organic matter from a modern metalliferrous hydrothermal sediment and their implications for banded iron formations. Chem. Geol. 77, 41-45 (1989).

132. Towe, K. M. Early Precambrian oxygen: a case against photosynthesis. Nature 274, 657-661 (1978).

133. Canfield, D. E. \& Teske, A. Late Proterozoic rise in atmospheric oxygen concentration inferred from phylogenetic and sulphur-isotope studies. Nature 382, 127-132 (1996).

134. Yung, Y. L. \& McElroy, M. B. Fixation of nitrogen in the prebiotic atmosphere. Science 203, 1002-1004 (1979).

135. Mancinelli, R. L. \& McKay, C. P. The evolution of nitrogen cycle. OriG. Life Evol. Biosph. 18, 311325 (1988).

136. Walker, J. C. G. Suboxic diagenesis in banded iron formations. Nature 309, 340-342 (1984).

137. Coates, J. D. \& Chakraborty, R. in Bioremediation: A Critical Review (eds Head, I. M., Singleton, I. \& Milner, M. G.) 227-257 (Horizon Scientific, Wymondham UK, 2003).

138. Kim, H. J. et al. A mediator-less microbial fuel cell using a metal reducing bacterium. Enzyme Microbiol. Technol. 30, 145-152 (2002).

139. Bond, D., Holmes, D., Tender, L. \& Lovely, D.R. Electrode-reducing microorganisms that harvest energy from marine sediments. Science 295, 483-485 (2002).

140. Tender, L. et al. Harnessing microbially generated power on the seafloor. Nature Biotechnol. 20, 821-825 (2002).

141. Bond, D. \& Lovley, D. Electricity production by Geobacter sulfurreducens attached to electrodes. Appl. Environ. Microbiol. 69, 1548-1555 (2003).

142. Bond, D. \& Lovley, D. Evidence for involvement of an electron shuttle in electricity generation by Geothrix fermentans. Appl. Envir. Microbiol. 71, 2186-2189 (2005)

143. Lovley, D. et al. Oxidation of aromatic contaminants coupled to microbial iron reduction. $\mathrm{Na}-$ ture 339, 297-299 (1989).

144. Coates, J., Anderson, R., Woodward, J., Phillips, E. \& Lovely, D. R. Anaerobic hydrocarbon degradation in petroleum-contaminated harbor sediments under sulfate-reducing and artificially imposed iron-reducing conditions. Envi- ron. Sci. Technol. 30, 2784-2789 (1996).

145. Coates, J., Anderson, R. \& Lovley, D. Oxidation of polycyclic aromatic hydrocarbons under sulfate-reducing conditions. Appl. Environ. Microbiol. 62, 1099-1101 (1996).

146. Anderson, R. T. \& Lovley, D. Naphthalene and benzene degradation under Fe(III)-reducing conditions in petroleum-contaminated aquifers. Bioremediation J. 3, 121-135 (1999).

147. Lovley, D. R., Phillips, E. J. P., Gorby, Y. A. \& Landa, E. R. Microbial reduction of uranium. Nature 350, 413-416 (1991).

This paper gives the first description of the microbially mediated reduction of hexavalent uranium.

148. Lovley, D. R. \& Coates, J. D. Novel forms of anaerobic respiration of environmental relevance. Curr. Opin. Microbiol. 3, 252-256 (2000).

149. Langmuir, D. Aqueous Environmental Geochemistry (Prentice-Hall, New Jersey, 1997).

150. Thamdrup, B. in Advanced Microbial Ecology (ed. Schink, B.) 41-84 (Kluwer Academic/Plenum Publishers, New York, 2000).

151. Dutton, P. L. \& Prince, R. C. in The Photosynthetic Bacteria (eds Clayton, R. A. \& Sistrom, W. R.) 525-570 (Plenum, New York, 1978).

\section{Databases}

Entrez Genome Project: http://www. ncbi.nlm.nih.gov/entrez/query. fcgi?db=genomeprj Chlorobium ferrooxidans

Dechloromonas aromatica Geobacter metallireducens Geothrix fermentans Marinobacter aquaeolei Rhodopseudomonas palustris Shewanella frigidimarina Shewanella oneidensis Shewanella putrefaciens Thiobacillus denitrificans

UniProtKB: http://ca.expasy.org/sprot CymA

MtrA

Cytc3

PpcA

\section{Further Information}

John D. Coates' homepage: http://pmb.berkeley.edu/ coates

Acknowledgments - Research on microbial redox cycling of iron in the laboratories of J.D.C. and L.A.A. is supported by grants from the US Department of Energy Environmental Remediation Sciences Program. 